\title{
A Review of Regional Economic Models with Special Reference To Labor Impact Assessment
}

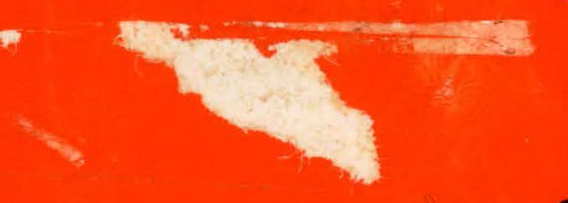

\section{Gregg Ferris \\ Bert Mason}
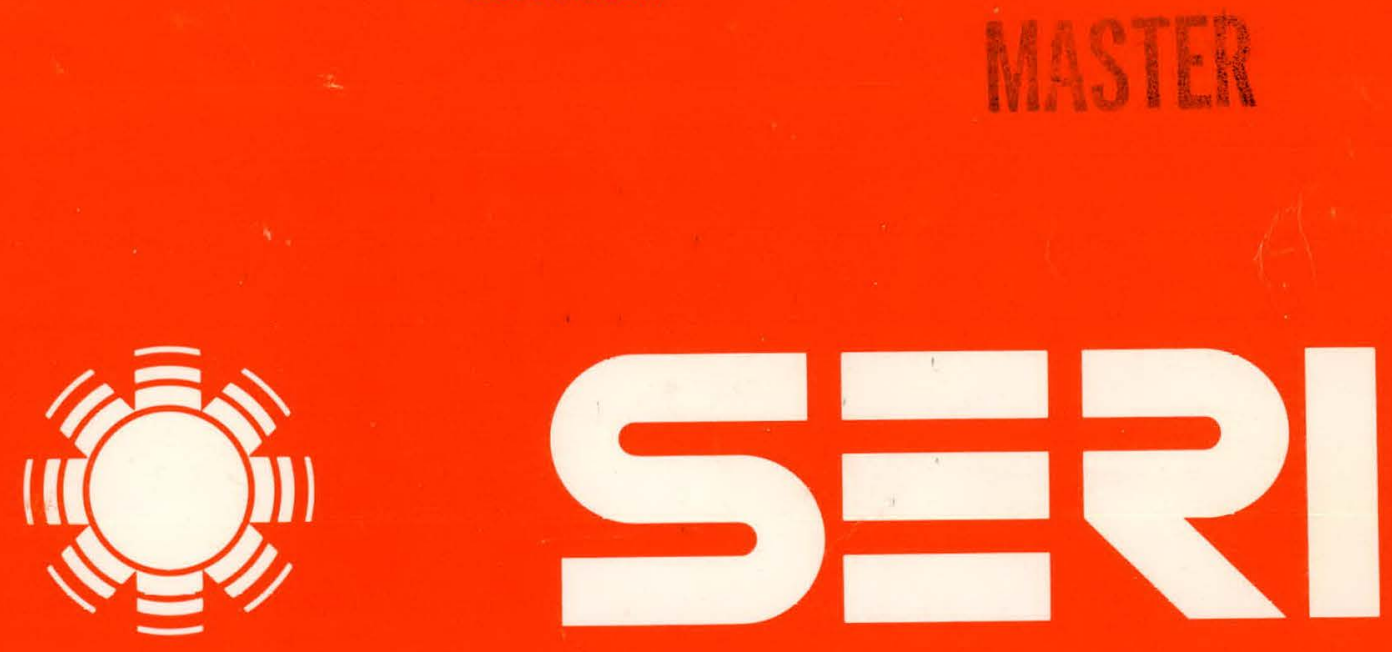

Solar Energy Research Institute A Division of Midwest Research Institute

1536 Cole Boulevard

Golden, Colorado 80401

Opcrated for the U.S. Department of Energy under Contract No. EG-77-C-01-4042 


\section{DISCLAIMER}

This report was prepared as an account of work sponsored by an agency of the United States Government. Neither the United States Government nor any agency Thereof, nor any of their employees, makes any warranty, express or implied, or assumes any legal liability or responsibility for the accuracy, completeness, or usefulness of any information, apparatus, product, or process disclosed, or represents that its use would not infringe privately owned rights. Reference herein to any specific commercial product, process, or service by trade name, trademark, manufacturer, or otherwise does not necessarily constitute or imply its endorsement, recommendation, or favoring by the United States Government or any agency thereof. The views and opinions of authors expressed herein do not necessarily state or reflect those of the United States Government or any agency thereof. 


\section{DISCLAIMER}

Portions of this document may be illegible in electronic image products. Images are produced from the best available original document. 


\author{
Printed in the United States of America \\ Available from: \\ National Technical Information Service \\ U.S. Department of Commerce \\ 5285 Port Royal Road \\ Springfield, VA 22161 \\ Price: \\ Microfiche $\$ 3.00$ \\ Printed Copy $\$ 5.254,50$
}

\title{
NOTICE
}

This report was prepared as an account of work sponsored by the United States Government. Neither the United States nor the United States Department of Energy, nor any of their employees, nor any of their contractors, subcontractors, or their employees, makes any warranty, express or implied, or assumes any legal liability or responsibility for the accuracy, completeness or usefulness of any information, apparatus, product or process disclosed, or represents that its use would not infringe privately owned rights. 
SERI $/ T R-53-100$

UC CATEGORY: UC-59,598,60,61,62,62A, $62 \mathrm{~B}, 63$

A REVIEW OF REGIONAL ECONOMIC MODELS WITH SPECIAL REFERENCE TO LABOR IMPACT ASSESSMENT

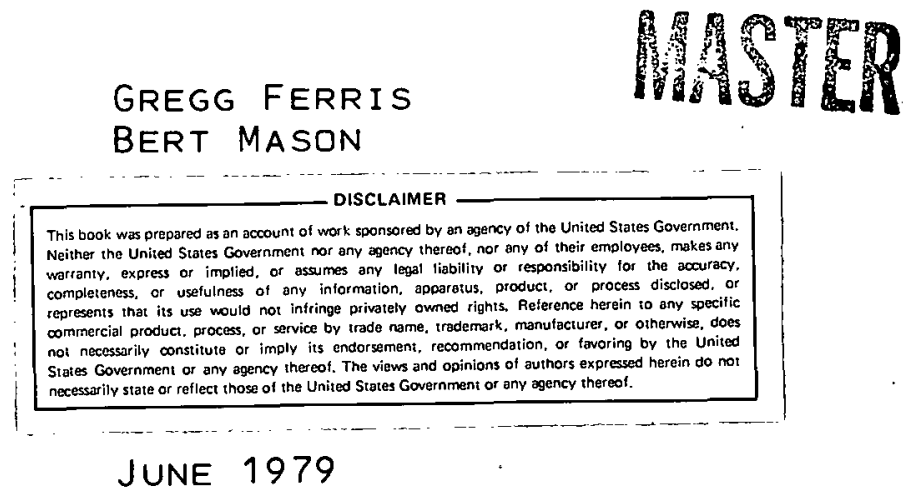

PREPARED UNDER TASK NÓ. 5379.10

\section{Solar Energy Research Institute}

15.36 Cole Boulevard

Golden, Colurado 00401

A Division of Midwest Research Institute

Prepared for the

U.S. Department of Energy

Contract No. EG $\cdot 77 \cdot \mathrm{C} \cdot 01 \cdot 4042$ 
THIS PAGE

\section{WAS INTENTIONALLY - ... LEFT BLANK}




\section{FOREWORD}

This report documents research conducted under SERI Task 5379.10. The authors are members of the Institutional and Environmental Assessment Branch of the Analysis Division.

Helpful comments by Theresa Flaim, Robert Witholder, and Barbara Burns are gratefully acknowledged.

\section{Rolut Oobler}

Robert Odland, Chief

Institutional and Environmental

Assessment Branch

Approved for

SOLAR ENERGY RESEARCH INSTITUTE

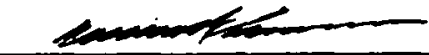

Melvin Simmons, Assistant Director

Analysis Division 
TABLE OF CONTENTS

$\underline{\text { Page }}$

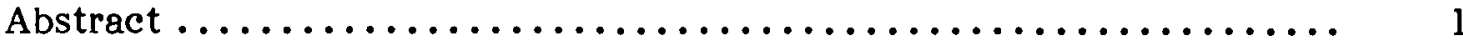

$1.0 \quad$ Introduction $\quad \ldots \ldots \ldots \ldots \ldots \ldots \ldots \ldots \ldots \ldots \ldots \ldots \ldots \ldots \ldots, 3$

$1.1 \quad$ Background..................................... 3

$1.2 \quad$ Organization $\ldots \ldots \ldots \ldots \ldots \ldots \ldots \ldots \ldots \ldots \ldots, \ldots \ldots \ldots, 4$

2.0 Overview of General Methods $\ldots \ldots \ldots \ldots \ldots \ldots \ldots \ldots \ldots \ldots \ldots \ldots$

$2.1 \quad$ Economic Base Analysis $\ldots \ldots \ldots \ldots \ldots \ldots \ldots \ldots \ldots \ldots \ldots \ldots$

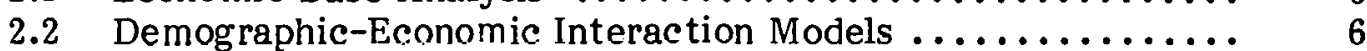

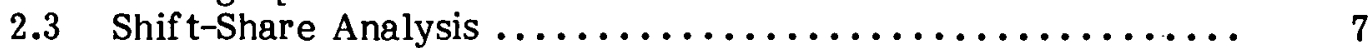

2.4 Input-Output (I-O) Analysis .................... 8

2.5 Industrial Location Analysis $\ldots \ldots \ldots \ldots \ldots \ldots \ldots \ldots \ldots \ldots \ldots \ldots$

3.0 Research Needs and Model Selection Criteria .............. 13

$4.0 \quad$ General Model Review $\ldots \ldots \ldots \ldots \ldots \ldots \ldots \ldots \ldots \ldots \ldots \ldots \ldots \ldots \ldots$

4.1 The Economic Activity Analysis (EAA) Model ........... 15

4.2 The Multiregional Input-Output (MRIO) Model ............ 15

4.3 The Multiregion Multi-industry (MRMI) Model ............. 15

4.4 The OBERS Model .......................... 17

4.5 The MULTIREGION Model..................... 17

4.6 The Regional Energy Activity and Demographic (READ)

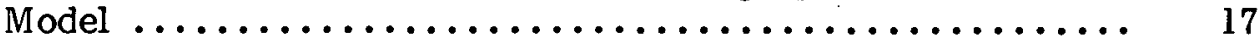

4.7 The Regional Earnings Impact System (REIS) Model ........ 17

4.8 The Regional Industrial Multipliẹr System (RIMS)

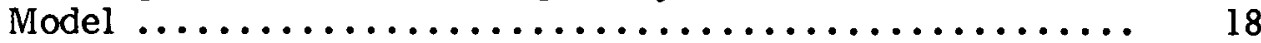

4.9 The Social and Economic Assessment Model (SEAM)........ 18

4.10 The Department of Labor (DOL) Model............... 18

5.0 Detailed Analysis of Relevant Models .................. 19

5.1 Regional Interindustry Multiplier Models ............. 19

5.1.1 The Economic Activity Analysis (EAA) Model ...... 19

5.1.1.1 Model Overview.................... 19

5.1.1.2 Methodological Observations............ 21

5.1.2 The Regional Industrial Multiplier System

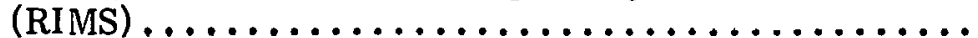

5.1.2.1 Model Overview.................. 22

5.1.2.2 Methodological Observations........... 22 


\section{Table of Contents}

(Continued)

Page

5.1.3 EAA and RIMS Comparison ............... 23

5.2 Interregional Models ....................... 23

5.2.1 The Multiregion Multi-industry (MRMI) Model ...... 24

5.2.1.1 Model Overview................... 24

5.2.1.2 Methodological Observations............ 24

5.2.2 The MULTIREGION Model............... 28

5.2.2.1 Model Uverview................. 28

5.2.2.2 Methodological Observations............ 31

5.2.3 MRMI and MULTIREGION Comparison ......... 32

6.0 Empirical Comparison of Model Output................. 33

6.1 The Regional Interindustry Multiplier Models............ 33

6.1.1 The California Model ..................... 33

6.1.2 The Colorado Region Models ................. 33

6.2 Regional Interindustry Multiplier Model Comparisons........ 34

6.3 The Interregional Models ..................... 38

7.0 Conclusions and Recommendations $\ldots \ldots \ldots \ldots \ldots \ldots \ldots \ldots \ldots$. 41

8.0 References............................... 43 


\section{LIST OF FIGURES}

$\underline{\text { Page }}$

2-1 Generalized Transactions Table ....................... 9

5-1 Simplified Flow Chart of Multiregional, Multi-industry

Forecasting Model............................. 25

5-2 Multiregion Computations During a Five-Year Time Step ....... 29

5-3 MULTIREGION within the Context of a National Economy ....... 30

\section{LIST OF TABLES}

4-1 Model and Model Characteristic Matrix ................ 16

5-1 Comparison of MRMI Model with Petersen's Study ........... 27

6-1 Sector and Multiplier (k) Comparison: San Francisco

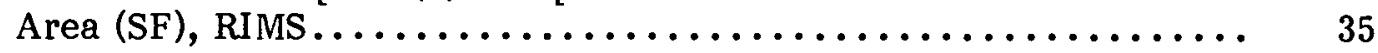

6-2 Sector and Multiplier ( $k$ ) Comparison: Western Colorado

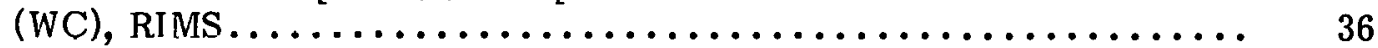

6-3 Sector and Multiplier (k) Comparison: Colorado State

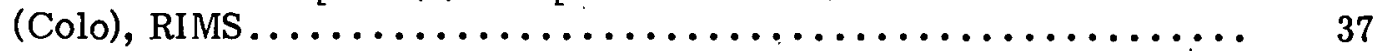

6-4 MRMI and Multiregion (MR) Forecasts Compared with Bureau

of Economic Analysis 1975 Employment Data .............. 40 


\begin{abstract}
This paper reviews several regional economic models and examines the capabilities of these models for assessing the total employment impacts of solar energy adoption. Five generic analytic methods are discussed: economic base analysis, shift-share analysis, demographic-economic interaction models, input-output analysis, and industrial location analysis. Ten regional models incorporating some aspect of these methods are reviewed.

From the model review, the conclusion is drawn that there is no single model that fits all of the necessary criteria for planned research efforts. Models that appear to hold promise are the Economic Activity Analysis (EAA) Model, the Regional Industrial Multipliers System (RIMS), the Multiregion, Multi-industry (MRMI) Model, and the MULTIREGION model.
\end{abstract}




\section{SECTION 1.0}

\section{INTRODUCTION}

\subsection{BACKGROUND}

There is growing interest among various individuals, groups, public agencies, and policymakers in the relationship between development of alternative energy sources and employment. Testimony presented before the Subcommittee on Energy of the Joint Economic Committee indicated that solar energy is more labor intensive than conventional sources and that commercialization of solar energy technologies would exert beneficial impacts on the labor market [1]. Evidence presented to the Subcommittee on Energy was admittedly piecemeal and preliminary, and no consistent or comprehensive method was used to evaluate the employment data presented.

As a result of this void in analysis and methodology, the Analysis and Assessment Division of the Solar Energy Research Institute (SERI) is undertaking the task of developing and implementing methods necessary to examine the regional employment implications of solar energy commercialization. The purpose of this paper is to document-by reviewing and critiquing available regional economic models-the initial steps in developing appropriate methodologies.

The objective of SERI's Task 5379.10 is to provide comprehensive analysis of the regional employment impacts of solar energy commercialization. To achieve this objective, the following research steps have been defined:

- estimate direct labor requirements for various solar energy technologies and applications;

- using regional economic models, estimate indirect and induced employment effects of solar energy commercialization; and

- compare the labor demands associated with solar energy with that in conventional energy industries and regional occupational pools.

This paper focuses on the second research step listed above: development of appropriate regional methodology.

A regional approach to estimate the employment impacts of solar energy was chosen for several reasons. First, the specific solar technologies and their extent of market penetration are likely to vary among regions. Regional economic and environmental conditions, such as heating and cooling requirements, insolation, cost, type, and specific uses of conventional energy sources, will be important in determining feasibility and the mix of solar technologies that will be employed. For example, simple "bread-box" solar water heaters may be appropriate in mild climate areas, while liquid antif reeze exchange systems may be necessary in colder regions. Each solar technology and application has unique input requirements, including the quantity and skill of labor. The type and cost of conventional energy sources will also be important. Economic feasibility for solar space heating will be affected, for example, by regional avallability of natural gas vs. electric resistance heat. For some technologies, such as biomass, regional resource availability must be considered also. 
A second reason for undertaking regional analysis is that changes in labor demand will exert differential effects on regional labor markets. For example, increased demand for skilled and unskilled labor will have different impacts in a region experiencing substantial unemployment in these skill categories than in an area with relatively tight labor markets. It is, therefore, necessary to estimate employment demand on a regional basis and relate these projections to regional labor supply.

\subsection{ORGANIZATION}

Impact estimation generally relies on modeling economic systems. This paper therefore identifies a set of regional impact models, and a list of criteria for evaluating the models is developed from research needs. Based on these criteria, models that are inappropriate are eliminated and those that hold potential for use in analyzing regional employment impacts of solar energy development are identified and disoussod in detail.

The report is organized in the following manner. An overview of the generic types of regional economic models is provided in Section 2.0. Those familiar with regional economic analysis methods can skip this section with no loss in continuity. In Section 3.0 , model requirements as dictated by research objectives are outlined and a set of model selection criteria is established. The general features of available regional models are reviewed and compared to research needs and objectives in Section 4.0. For those not interested in the discussion of individual models, it is recommended that Table 4-1, which compares the salient character istics of each model, be examined carefully.

In Section 5.0, a more detailed analysis of the models considered useful (as determined by research criteria established in Section 3.0) is presented. To provide some indication of the consistency and "accuracy" of the models chosen for detalled consideration, empirical estimates provided by the general models are compared to thuse of reglonspecific models that are based largely on primary survey data (Section 6.0). Data in Tables 6-1 through 6-4 summarize the results of these comparisons. In Section 7.0, conclusions on the usefulness and potential of the various models to ussexs regional/employment impacts are drawn from the structural examinations and empirical comparisons. 


\section{SECTION 2.0}

\section{OVERVIEW OF GENERAL METHODS}

There are five general methodologies that can be used to estimate labor market impacts associated with some change in a local or regional economy. These include economic base analysis, demographic-economic interaction models, shift-share analysis, inputoutput (I-O) analysis, and industrial location analysis. The methods used to implement these techniques vary in approach, sophistication, and data requirements. Most applied models are not pure forms of any single technique but incorporate elements of several methods. The general tenets of each method are outlined in this section.

Before proceeding, several terms that will be used throughout the report need to be defined. Multiregional is used to describe a model which can be applied to more than one region. An interregional model is one that can be used to estimate the impact associated with a change in a local economic system and the effects of that change elsewhere in the larger economic system within which the local system is contained. A multiplier is defined as a parameter which indicates the relationship between an exogenous change impacting a region and the total effect occurring after the regional economy has reached equilibrium. Typically, this multiplier is divided into the initial (direct) effect and all other (indirect) effects.

\subsection{ECONOMIC BASE ANALYSIS}

The economic base approach to multiplier estimation divides all economic activity into two categories. The first category, basic activity, measures the local industry production change brought about by a change in demand for the output of local firms. The second category, service activity, measures the production change that occurs in local industries which are supplying goods and services to the basic industries and their employcco. The analysis, in its sinplest form, estimates multipliers through the following general for mulation:

$$
k=\frac{\Delta B+\Delta S}{\Delta B}
$$

where: $\quad k=a$ multiplier

$$
\mathrm{B}=\text { basic economic activity }
$$

$\mathrm{S}=$ service economic activity

In applying this technique, the change in local economic demand is generally defined as a change in export demand. The logic of the technique is that demand arising outside a local economy disturbs the equilibrium position of the local economy and engenders an output response within the local economy. As the local industries respond to this export. demand, secondary demand is generated in local industries supplying inputs to the exporting industry and industries supplying goods and services to wage earners in the affected industries.

In practice, this technique can be expected to yield imprecise estimates of multiplier effects for scveral reasons. The sepalution of un economy into export and service industries is an arbitrary delineation which can be subject to a considerable range of 
error when a gross industrial sector (e.g., at the two-digit level of SIC code aggregation) is classified strictly as an export sector. It is more likely that a given industrial sector will have both export and service activity, but it is usually difficult to allocate total sector output between export and service activities. Achieving accuracy in such an identification procedure requires detailed survey-type information. However, economic base analysis is generally used when detailed, survey-type data are unavailable. As a result, economic base analysis is of ten forced to rely on indirect methods for estimating sectoral exports. Such indirect methods have important limitations and add a greater degree of uncertainty to the overall analysis.

One example of a well-known indirect export-estimating technique is the location quotient method. Location quotients attempt to measure export activity by measuring the relative over- or under-representation of an industry in a region as compared to the nation. A typical location quotient is defined as follows [2]:

Location Qụotient $i j=\frac{E_{i j} / E_{j}}{E_{i o} / E_{o}}$

where: $E_{i j}=$ employment in industry $i$, region $j$

$E_{j}=$ total employment in region $j$

$\mathrm{E}_{\mathrm{jo}}=$ employment in industry $\mathrm{i}$ in the United States

$\mathrm{E}_{\mathrm{O}}=$ total employment in the United States

If a location quotient is greater than unity for a particular industry, it is defined as an export industry.

There are two major limitations of this method. The first is the assumption that there is no cross-hauling among regions. The assumption states that if a region exports a good or service the region does not import that partlcular good or service. In reality, bccause of product mix, price differentials, and brand preferences, cross-hauling exists. The problem is somewhat exacerbated when gross sectoral aggregations are used in the analysis. The second limitation is the implicit assumption that regional labor productivity equals national productivity.

Economic base analysis is designed to handle, at best, gross changes in the level of demand. Economic base analysis cannot easily address alteration of the composition of demand. In addition, the analysis does not normally account for the variance in industrial composition observed over time and across space. Finally, the technique is generally not capable of providing insight Into the pattern of inler industry linkages in an cconumy.

\subsection{DEMOGRAPHIC-ECONOMIC INTERACTION MODELS}

This general class of models is used to forecast social or economic data and, then, to derive other needed data through proportioning or econometric techniques. For example, a typical estimation sequence computes regional population via cohort-survival and migration algorithms. Economic data are estimated by applying various ratios, such as labor force participation rates, to the estimated population to obtain estimates of total regional employment. Multipliers are estimated by determining the ratio of basic 
employment to service employment. These models are of ten used in very localized studies where a wide variety of data is available. At least one attempt has been made to generalize this approach to broader regional areas. This technique is discussed in a subsequent section.

Demographic-economic interaction models have several limitations with respect to the stated research needs. First, migration algorithms are used to estimate regional population. Estimating migration patterns is a particularly difficult exercise and-precise estimates are not readily assured by even sophisticated, state-of-the-art methods [3]. The frequent use of proportioning techniques further detracts from the accuracy the method can be expected to achieve. This is especially true when the proportions used are averages derived from several disparate groups. Also, the multipliers derived from simple basic-service ratios do not offer great insight into the complex set of phenomena forming the multiplier.

\subsection{SHIFT-SHARE ANALYSIS}

Shift-share analysis is a technique that is used to estimate and project a regional economic growth rate by dividing the rate into several components. The rate of growth of each component is then estimated from historical time series data and forecasted via trending. A typical shif $t$-share equation is specified as follows [2]:

$$
E_{i, t_{n}}^{R}=\left[1+r_{i, t_{0}, t_{n}}^{u S}+C_{i, t_{0}, t_{n}}^{R} E_{i, t_{0}}^{R}\right.
$$

where: $E$ = employment

$\mathrm{i}=$ industry

$\mathrm{t}_{\mathrm{o}}=$ time

$t_{n}^{o}=$ estimation period

$\mathrm{R}=$ subnational region

US = national total

$$
\begin{aligned}
& r \text { - regional share effect }=\frac{E_{i, t_{n}}^{U S}-E_{i, t_{0}}^{U S}}{E_{i, t_{0}}^{U S}} \\
& C=\text { regional shift effect }
\end{aligned}
$$

The specification of this equation indicates that regional industrial employment levels in the estimation period can be expressed as the level of employment in the base period multiplied by unity plus the national growth rate of industry $i$ over the period $t_{1}{ }^{-t} u_{\text {, plus }}$ the rule of growth of industry $i$ over the period $t_{n}-t_{0}$ that equates regional and national growth. This latter growth rate is a residual that equilibrates the observed growth rate of $E_{i}^{R}$ with what $E_{i}^{R}$ would have been if $E_{i}^{R}$ had grown at the same rate as $E_{i}^{U S}$. This variable indicates the locational advantages or disadvantages of producing in region $R$.

The value of this method lies in its simplicity in concept and data requirements. There are, however, several disadvantages inherent to shift-share analysis. First, it does not 
yield any insight into the causes of economic growth. Second, the method is not suited to impact analysis because no differentiation is made between endogenous and exogenous variables. Third, the technique is incapable of picking up trend reversals. Finally, the analysis does not provide insight into the interindustry linkages in an economy.

\subsection{INPUT-OUTPUT (I-O) ANALYSIS}

The basic component of $1-O$ analysis is a matrix, called a transactions table, which indicates dollar flows from producing sectors to consuming sectors for both intermediate and final use. Any cell element of any column in the table indicates the dollar amount that a consuming industry purchases from a producing industry. Alternatively, any cell element of any row in the table indicates the dollar amount that a producing industry sells to a consuming industry. For analytical purpuses, the transactions tuble is converted into a table of direct coefficients and a table of direct and indirect cnefficients. The construction and use of these latter tables are outlined below.

The table of direct or technical coefficients expresses each cell element of the transactions table as:

$$
\frac{x_{i j}}{x_{j}}=a_{i j}
$$

where: $x=$ an element in the transactions table expressed in dollars

$\mathrm{i}=$ row

$\mathrm{j}=$ column

$a=$ technical coefficient

A given element, $a_{i j}$, of the table of direct coefficients indicates the proportion of the total cost of product $j$ that is accounted for by the cost of input $i$. The complete table is often referred lu as the A matrix.

The technical coefficient table indicates the linkages among industries in a given regional economy. The technical coefficient matrix is usually converted to a table of direct and indirect coefficients, which enables the analyst to estimate the multiplier effect of an exogenous change in an economy.

In order to understand the process of estimating I-O multipliers, the transactions table must be considered in detail. In Figure 2-1, an illustrative example of a transaction table is provided. The columns of the transactions table are generally referred to as the purchasing scetoro, whilc tho rowe ropresont the produsing sertars. The purchasing sectors are divided into two components of demand, intermediate (A matrix) and final. The producing sectors are divided into intermediate and primary input sectors. A change in the level of one of the components of final demand is the action which begins the multiplier estimation. The multiplier is determined by multiplying the original final demand change by the matrix of direct and indirect coefficients. The derivation of the latter matrix is detailed below. 


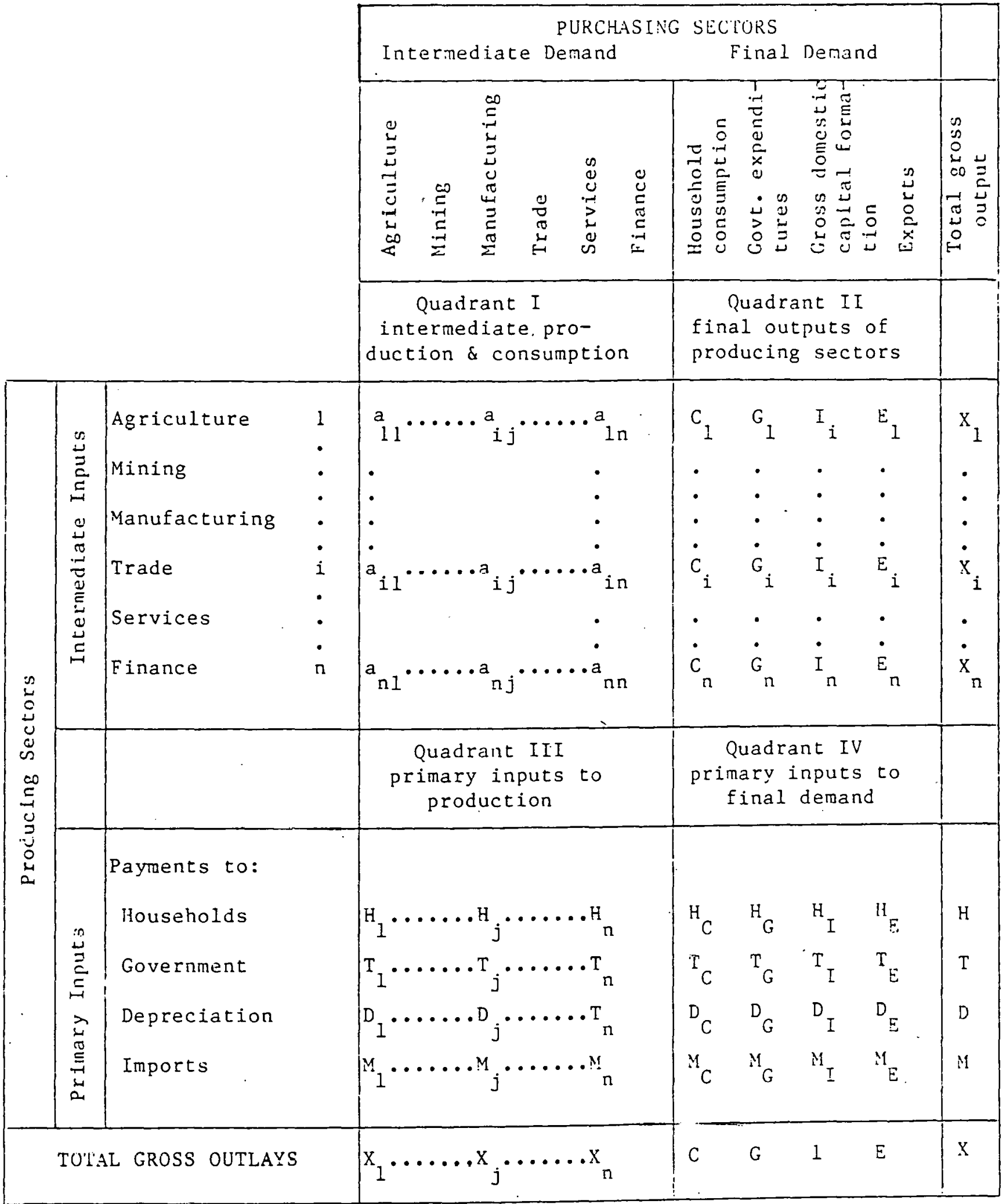

Figure 2-1. Generalized Transactions Table [4] 
Any row in the system detailed in Figure 2-1 can be expressed as:

$$
X i=\sum_{j=1}^{n} a_{i j} x_{j}+\sum_{j=1}^{n} Y_{i j}
$$

In matrix notation, the complete system can be expressed as:

$$
\mathrm{X}=\mathrm{AX}+\mathrm{Y}
$$

where: $X=$ the vector of total outputs

$A=$ the technical coefficients matrix

$\mathrm{Y}=$ the vector of final demand

Eyuation (3) can be rearranged to:

$$
(1-A) X=Y
$$

where: $I=$ the identity matrix

To develop a solution, both sides of equation (4) are premultiplied by (I-A) which yields:

$$
(I-A)^{-1}(I-A) X=(I-A)^{-1} Y
$$

which reduces to:

$$
X=(I-A)^{-1} Y
$$

Equation (6) is the meohanism through which 1-O multiplier effects are retermined. For example, if an ennnnmy's oxports shünge due to some exogenous forces, the effect on total output would be given through the $(\mathrm{I}-\mathrm{A})^{-1}$ matrix, the matrix of direct and indirect coefficients. There are three general types of multipliers calculated via equation (6).

The first type is an output multiplier. This multiplier is defined as the total (dirent and indirect) output responec Associated with a unit change in final demand. It is derived by summing the coefficients in the impacted industry's column of the matrix of dlrect and indireot coefficients.

The second type of multiplier that can be developed is the employment multiplier. This quantity is estimated by multiplying the matrix of direct and indirect coefficients by an exogenous diagonal matrix of labor coefficients. These multipliers can also be estimated by multiplying total output estimates by the ratio of employees per dollar of output.

The third type of multiplier is the income multiplier. An income multiplier can be estimated in two ways. A Type I lncome multiplier is obtained by defining an A matrix row vector whose cell elements are the proportion of total output allocated to wages and salaries (wage row). The next step is to sum the products of multiplying each row entry in each column in the table of direct and indirect coefficients by the A matrix wage row coefficient of the corresponding column. This sum yields the direct and indirect income 
change associated with a unit change in industry output. The Type I multiplier is expressed as the ratio of the direct and indirect change to the direct income change. This multiplier does not include the effects of the spending of wage earners in the affected industries.

Type II income multipliers estimate the total income change associated with a unit income change paid to wage earners. The multiplier is estimated by including a personal consumption expenditure ( $\mathrm{PCE}$ ) column and a wage row in the A matrix.* Subtracting this augmented A matrix from the identity matrix and inverting the result yields a matrix of direct and indirect coefficients (where households are endogenous). An element in the wage row indicates the total (direct, indirect, and induced) income change associated with a unit change in output in a given sector. Dividing this total change by the appropriate A matrix wage row coefficient yields a Type II income multiplier.

Although I-O analysis can provide considerable insight into the structure and interaction among sectors of an economy, the approach has several limitations. Developing the table of direct coefficients requires considerable data collection effort. A number of other criticisms stem from the static nature of the model. Over time, technology and prices can be expected to change and alter the proportional distributions among sectors in the $\mathrm{A}$ matrix. Another important observation, which is particularly critical in local I-O models, is that an alteration of trading patterns over time can produce significant differences between the true interactions and those represented in the A matrix. For example, this can occur if firms shift to importing goods that were produced locally at the time the table was constructed. This situation would change the relationship of the $a_{i j}$ 's with one another and invalidate the technical coefficients tables.

Another criticism of $\mathrm{I}-\mathrm{O}$ models is that they do not necessarily account for forward production linkages. These linkages can occur when firms relocate to an area because the area has a primary industry with which the relocating firms can interact. This change in interindustry structure usually occurs in the context of regional growth. Again, it is difficult to incorporate dynamic aspects into traditional I-O analysis.

\subsection{INDUSTRIAL LOCATION ANALYSIS}

Industrial location analysis is based on the premise that changes in the location of Industry are the main driving forces behind regional growth. In general, this type of analysis uses econometric techniques to estimate the location of industry. Typically, the level or change in output (earnings or employment) is specified as being functionally related to input supply variables, transportation variables, and agglomeration variables.** Input data are usually derived from $1-0$ tables through a consideration of the relative importance of various inputs. Transportation variables use data that indicate the cost of transporting goods to and from markets. Agglomeration variables usually employ data that describe a region's purchasing power, population levels, economic structure, geographic location, and labor market conditions.

*A PCE column is compused of elements that equal sectoral PCE divided by total PCE.

**Agglomeration variables delineate region size. 
Industrial location analyses generally derive multipliers through simulation procedures. For example, a baseline simulation is run for a business-as-usual economy. Subsequently, certain data items are altered to reflect scenario-specified conditions and the model is run again. The results of the base case simulation are subtracted from the scenario simulation and the multiplier effect is observed as the residual.

Industrial location analysis has several advantages. The use of econometric techniques enables the analyst to build some dynamic aspects of economies into the modeling effort. The primary data requirements for calibrating the model are less than those normally required for I-O models, and the data base can of ten be pooled with both time series and cross-section data. Perhaps most important, the analysis can be based firmly on economic theory and, thereby, enhance the expectation for accurate forecasts over time.

The disadvantage of industrial location analysis is that the demands of econometric practice of ten result in circuitous methods of parameter estimation. For example, proxy variables are often used to represent a varlable for which no reul duta mieasurements exist. The result is that the estimated equation may not reflect the theoretical relationship. Another limitation is that parameters estimated for a base period can be expected to change over time and must be updated periodically. 


\section{SECTION 3.0}

\section{RESEARCH NEEDS AND MODEL SELECTION CRITERIA}

As suggested in Section 1.0, development of the solar energy industry can be expected to vary widely in terms of the region, level, and timing of that development. It would be useful, therefore, to maintain the capability to estimate the employment impacts as the region, level, and timing of the development become apparent. To provide information necessary to plan programs and policies facilitating solar energy development, it is important to assess the socioeconomic impacts, particularly employment effects, of specified solar energy market penetration estimates. These tasks imply several characteristics which the estimating technique must have in order to supply relevant data.

Techniques employed in estimating impacts associated with energy commercialization of ten involve modeling economic processes. Developing the capability for such modeling can be a lengthy and resource-intensive process. As a result, it was decided at the outset that an existing model(s) would be adapted to research needs.

To determine regional employment impacts of solar energy commercialization, the following capabilities are necessary.

- The model must be based on internally consistent logic which incorporates stateof -the-art regional economic theory.

- The model must be capable of producing results for all regions in the country.

- The model should be interregional.

- The multiplier technique used in the model should be based on interindustry relationships.

- The model should offer reasonable industrial detail.

- The model should be currently operational.

- The model must be capable of estimating regional employment impacts.

- The cost of using the model must fit within project budget constraints.

In order for any regional economic analysis technique to be useful in assessing economic impacts of solar energy development, it is essential that the technique be based on logically consistent regional economic theory. As explained above, the research in the field of regional economic theory has produced several accounting techniques for estimating regional economic relationships. The choice for any one technique should follow, first, from project output requirements and model input requirements. Once these have been determined, the set of regional models can be searched for one that meets these requirements in a theoretically appropriate manner. The ultimate selection of a model must be based on consistency between the model methodology and regional economic theory. The sections that follow develop this theme more completely.

Project requirements dictate that the model selected can be applied to all regions of the country. This requirement implies that a set of different models covering the country will not be appropriate, since different methods are based on different definitions and conventions which make comparison of output among models difficult, if not impossible. 
Choosing a single model enables a more consistent comparison of impact estimations across different regions.

The geographical level at which model outputs are generated is important. Small units of observation, such as counties, are generally preferable since smaller areas can be aggregated to larger areas, but the converse is not usually true. The geographic unit at which model outputs are reported would be most useful if that unit could be aggregated to a majority of political economic units (e.g., states and SMSAs). The difficulty with generating small area data is that most model results of ten develop sampling problems when reporting output for very disaggregated regions. These problems of ten affect the validity and, therefore, the usefulness of the model's output data.

In order to account for all impacts resulting from an initial change, another important aspect is that the model should have the capability to be used to assess interregional

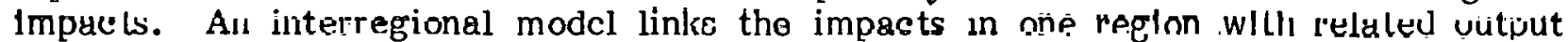
impacts in all other regions in the system. Without this capability, the analyst can perform only a partial assessment unless the specific region is a wholly self-sufficient economic unlt (an unlikely situation).

All impact analysis methods employ some technique for estimating the secondary effects associated with a change in an economic system. As mentioned earlier, there are several general techniques for estimating these secondary or multiplier effects-economic base analysis, simulation analysis, and I-O analysis. All techniques can result in approximately equivalent multipler estimates. Input-output, however, has the advantage of enabling the analyst to determine precisely the industrial linkages among the impact industry, industries supplying inputs to the impact industry, and consumer spending patterns.

In order to assess the impact of solar energy development comprehensively in a given region, it is necessary to have regional data at a reasonable level of industrial detail. This detail can permit analysis that focuses on sectors important to solar energy development. Such disaggregation also enables the analysis to focus directly on relevant industry interactions. In addition, since the analysis centers on energy impacts, it would be useful if the model chosen has a disaggregated energy sectoring scheme.

Since the ultimate objective of the research is to estimate total employment impacts, it is desirable to utilize a model that estimates employment data explicitly. Many models estimate employment by applying an employee-per-output ratio to output estimates. While this procedure is common, it is not desirable when variations in productivity over time or geographic location are expected. Appropriate specification of employment estimating equations will account for productivity variations and contribute to estimation acecuracy.

Finally, several pragmatic concerns need to be considered. The current project must be accomplished within a relatively short period of time. Multiplier estimation techniques that are not currently operational are not useful. Another concern is that project resources are limited. Models that are expensive are also excluded from consideration. Finally, a candidate model must be fully documented in order to assure that it can be used properly. 


\title{
SECTION 4.0
}

\author{
GENERAL MODEL REVIEW
}

Several regional and interregional models have been identified which are potentially useful for this study. The models' origins and features are varied, but all are attempts to model regional economic activities. The approach of this overview is to list the relevant features of all the models and eliminate from consideration those models not possessing the minimal needed features. To aid in organizing this review, Table 4-1 lists the models to be discussed in the left-hand rows and the important model features in the column headings. Any cell element of the resulting matrix describes a given feature of the model listed in that row.

\subsection{THE ECONOMIC ACTIVITY ANALYSIS (EAA) MODEL [5]}

The Bureau of Land Management maintains an economic impact model, the EAA model. This model is based on the 1971 National I-O Table and produces county-level multiplier estimates that are reported in terms of earnings. Since the county is the reporting unit, the model fits the multiregional criterion although it is not interregional. The general sectoring scheme is highly aggregated (16 sectors) but there is a separate public utilities sector. The model is operational and deserves further consideration for use in the current project.

\subsection{THE MULTTREGIONAL INPUT-OUTPUT (MRIO) MODEL [6]}

The MRIO model is part of the Harvard Economics Research Project. The model meets many of the criteria required by this project. It is multiregional and interregional. The' model is of the I-O type, and has a highly disaggregated sectoring scheme. Several drawbacks, however, decrease its utility for this study. First, it is not clear that the model is currently operational. Even if it were operational, since the model is fully interregional, the cost of running the model for a specific area would be the same as a full regional/national scenario run. In addition, model outputs are highly aggregated and are reported only by state. Finally, the model is based on the 1963 National I-O Table and does not reflect recent changes in economic structure.

\subsection{THE MULTIREGION MULTI-INDUSTRY (MRMI) MODEL [7]}

The MRMI model was developed by Curtis Harris, Jr. of the University of Maryland, and has been used by several federal agencies. The model is multiregional and interregional. The model has 99 sectors of which three are energy sectors. The model is based on industrial location theory and the parameters are estimated via econometric techniques. The geographic unit for which data are generated is the county and data are reported in terms of output, employment, and earnings. The model estimates employment multipliers by comparing employment data from a base case with results from a variation of the base case. This process is fairly complex and therefore expensive for repeated application to small area studies. For determining the regional/national effect of major policy scenarios, this model seems to offer a good state-of-the-art alternative, and is given a more in-depth assessment in Section 5.0. 
Table 4-1. MODEL AND MODEL CHARACTERISTIC MATRX

\begin{tabular}{|c|c|c|c|c|c|c|c|c|c|c|c|}
\hline Model & $\begin{array}{l}\text { Model } \\
\text { Type }\end{array}$ & $\begin{array}{l}\text { Multi- } \\
\text { Regionai }\end{array}$ & $\begin{array}{l}\text { Integ- } \\
\text { Regional }\end{array}$ & $\begin{array}{l}\text { Numbe: } \\
\text { of } \\
\text { seztors }\end{array}$ & $\begin{array}{l}\text { Utility } \\
\text { Sectoring }\end{array}$ & $\begin{array}{l}\text { Analytic } \\
\text { Method }\end{array}$ & $\begin{array}{l}\text { Output } \\
\text { Data }\end{array}$ & $\begin{array}{l}\text { Regional } \\
\text { Cnit }\end{array}$ & $\begin{array}{l}\text { Model } \\
\text { Status }\end{array}$ & $\begin{array}{l}\text { Data } \\
\text { Base } \\
\text { Year }\end{array}$ & $\begin{array}{c}\text { Full } \\
\text { Documentation }\end{array}$ \\
\hline EAA & $\mathrm{I}-\mathbf{0}$ & Yes & No & 16 & J & EB & $\mathrm{E}$ & County & Operational & 1571 & No \\
\hline MHIO & $1-0$ & Yes & $Y \in S$ & ४9 & I & $1-0$ & $\mathrm{O}, \mathrm{E}, \mathrm{N}$ & State & $?$ & 1963 & Yes \\
\hline MKMI & IL & Yes & Yes & 99 & $\#$ & $\mathbf{s}$ & $\mathrm{O}, \mathrm{E}, \mathrm{N}$ & Coiınty & Operational & 1970 & Yes \\
\hline OBERS & SS & Yes & Yes & 37 & $\mathbf{N}$ & EB & $E, N$ & BE.1 State & Operational & 1970 & Yes \\
\hline ORNL & $D-E$ & íes & Yes & $£ ?$ & 1 & EB & $\mathbf{N}$ & BEA & Operational & $19^{\circ} 0$ & Yes \\
\hline READ & IL & res & Yes & 47 & $\#$ & $\mathbf{s}$ & $O, E, N$ & SMSA & Not Operational & $19: 2$ & No \\
\hline REIS & $\sqrt{I-0}$ & Yes & Yes & 37 & $\cdot \mathbf{I}$ & EB & $\mathrm{E}$ & Staie & Operational & 19.1 & Yes̀ \\
\hline RIMS & $1-0$ & Tes & No & $5 \hat{s}$ & $\mathbf{N}$ & Econ & 0 & SMSA & Operational & $19 E 7$ & Yes \\
\hline SEAM & $\mathrm{D}-\mathrm{E}$ & Yes & No & IJ & $\#$ & EB & $\mathbf{N}$ & Counity & Ope:ational & 1972 & Yes \\
\hline UTAH & EB & $\mathrm{ro}^{*}$ & No & 70 & I & EB & $\mathrm{N}$ & Counly & $\begin{array}{l}\text { Not Fully } \\
\text { Operational }\end{array}$ & 1972 & No \\
\hline
\end{tabular}

\section{LEGEND:}

I-0 input-output anzlysis

IL i.zdustrial location t ieory

SS shift-share analysis

D-E demographic-econonic

interaction anialysis

EB economic base enalysis
1 ore indegendent utility sector

L energy sector nested in a larger sectorel eggregetion

several independert utility sectors

Econ economic techniques

s. simulation comparisons

\section{$\dot{E} \quad$ earring}

\section{O output}

$\mathrm{N}$ employment

BEA functional economic area that ineludes both regional labor supply and labor demand

SMSA stanäard metropolitan

*DOL Region VIII only. 


\subsection{THE OBERS MODEL [8]}

The Office of Business Economics in the Department of Commerce and the Economic Research Service in the Department of Agriculture have developed a regional economic model titled OBERS. This model employs a shift-share approach to modeling regional populations. Trend analysis is used to estimate total employment through labor force participation rates and regional shares of total employment. The model is multiregional and interregional although these characteristics are static. OBERS breaks industrial activity into 37 groups and reports data for states, BEA economic areas, and SMSAs. Multipliers can be implied through economic base analysis. Since economic base analysis does not permit sufficient insight into an economy's interindustry linkages, the OBERS model is not appropriate for the proposed research.

\subsection{THE MULTIREGION MODEL [2]}

MULTIREGION is a model developed by Oak Ridge National Laboratory (ORNL). The model is built upon the notion that a region's economy should be viewed as a labor market and therefore focuses on phenomena affecting labor supply and demand. The model is multiregional and interregional. Regional industrial composition is divided into 37 sectors with public utilities comprising one independent sector. The model's parameters are estimated through econometric techniques and multipliers are calculated through simulation analysis. Model output is reported for BEA economic areas and can allocate these BEA totals to counties. The model encompasses many features needed in the present research and is given more detailed consideration in Section 5.0.

\subsection{THE REGIONAL ENERGY ACTIVITY AND DEMOGRAPHIC (READ) MODEL [9]}

The READ model is being developed by DOE.* This model employs econometric techniques and industrial location theory to forecast the impacts of national energy policies upon economic activity, the location of industry, population and employment, the activities of state and local government, and the environment. READ is a comprehensive, interregional, county-level model. The model disaggregates industrial activity into 51 sectors of which public utilities is an independent sector. In theory, READ would be appropriate for the type of analysis to be performed here, but the model is still in the development stage and its operational date is unknown at the time of this writing.

\subsection{THE REGIONAL EARNINGS IMPACT SYSTEM (REIS) MODEL [10]}

The REIS model is a Department of Energy "tops down" modeling method for estimating regional earnings.' The model converts national employment estimates to the BLS I-O industry classification scheme and then distributes these totals to states based on OBERS data. The model is multiregional and interregional. 'The model's multipliers are derived

\footnotetext{
*I'he hevelupment of the R.FAD model currently has been suspended indefinitely.
} 
via economic base analysis. This latter characteristic and the aggregated unit of analysis (state level) make the model inappropriate for assessing the regional employment impacts of solar energy.

\subsection{THE REGIONAL INDUSTRIAL MULTIPLIER SYSTEM (RIMS) MODEL [1 $]$}

The Bureau of Economic Analysis (BEA) in the Department of Commerce has producer the RIMS model. This model is based nn tho BEA Natiunlul input-Output Table. The model uses lala reported in County Business Patterns to regionalize the national table and rcflect locul interindustry configurations [12]. The model is multiregional. Regional industrial structure is detailed in any user-specified number of sectors up to a maximum of 478. The model is currently operational and produces data at the county level but, according to the model's designers, the datu appear to be more reliable when several counties are aggregated. The multipliers generated from the RIMS process are output multipliers that can be translated indirectly into einployment multipliers. This model appeal's to hold potential for use in the present study and will be considered in further detail.

\subsection{THE SOCIAL AND ECONOMIC ASSESSMENT MODEL (SEAM) [13]}

Argonne National Laboratories has produced a county-level impact estimation model, SEAM. Employment is estimated by applying labor force participation rates to population estimates. The model is multiregional. It incorporates a data base that has detailed information on construction and operation requirements for several energy sectors but generates output for only 10 sectors. The model is operational and appears able to produce reliable estimates of employment inpacts through a lagged economic base mudel. The lagged multiplier spreads impacts over several periods. The use of economic base analysis and the aggregated sectoring scheme reduces the model's utility for this research for reasons mentioned above.

\subsection{THE DEPARTMENT OF LABOR (DOL) MODEL [14]}

The Regional Industrial-Occupational Labor Demand Model is being developed for the Department of Labor by the University of Utah. The model uses economic base analysis and econometric methods to estimate the employment impacts of exngenous shocks lo a regional economy. This model also uses a distributed-lag technique to spread the impact of demand over industries and time. The model has 70 sectors and breaks this industry detail into 400 industrial occupations. The model's output is reported for counties. The Labor Demand Model is currently operational for counties in Federal Region VIII.* The model holds potential for use in employment impact estimation endeavors, but its economic base structure and narrow geographic applicability limit its utility for the present study. The model may be very useful, however, in validating the results of another multiplier technique more closely applicable to this study's needs-especially since several of the states in Region VIII can be expected to have considerable solar energy development.

*Federal Region VIII includes the following states: Colorado, Montana, North Dakota, South Dakota, Utah, Wyoming. 


\section{SECTION 5.0}

\section{DETAILED ANALYSIS OF RELEVANT MODELS}

The preceding section indicated that several models have capabilities that match reasonably with those needed in the present research. Specifically, EAA and RIMS appear capable of estimating the county-level employment impacts of solar energy development with an I-O technique. The I-O technique is particularly useful because of its capability to examine interindustry linkages. MRMI and MULTIREGION can be used to estimate employment impacts for counties and BEA economic areas, and they can address interregional employment effects of solar energy commercialization.

\subsection{REGIONAL INTERINDUSTRY MULTIPLIER MODELS}

For evaluating the impacts of solar energy development in specific areas, it is important to have a modeling capability that can produce multiplier analysis based on a local economy's structure. The EAA and RIMS models are built on I-O relationships and appear capable of providing reasonable insight into industrial linkages and employment implications of demand changes on local production facilities. Neither of these models has interregional capabilities, so they can make only a partial contribution to the overall analysis.

\subsubsection{The Economic Activity Analysis (EAA) Model}

The Bureau of Land Management has recently sponsored the development of the EAA model. Detailed documentation is not presently available, but the model was recently summarized by Alan Dickerman [4]. This review will depend heavily on the discussion provided by Dickerman.

\subsubsection{Model Overview}

The EAA model provides a description of regional economies and the relative impacts of industries on changes in personal income. The model uses industry earnings in combination with a 16-sector, expected transactions matrix compiled from the $1971 \mathrm{BEA}$ National I-O Table. The model uses these data to estimate net exports or imports by industry for an economy of a given area. From these estimates, income multipliers for each industry are computed. The multipliers refer to impact on personal income (earnings) rather than business income (sales). The EAA model is designed to use earnings data as a consistent source of economic information for all regional areas. Although the model uses national data to express local interindustry linkages; it allows variations in the structure of local economies by utilizing estimates of each region's industrial earnings mix. The model assumes unif orm production functions for each firm in a given industry. The model can be applied to any region for which earnings data are available. Extensive empirical tests show the model to be sensitive to variation in industry earnings and geographic delineation [4].

The EAA technique estimates industry multipliers in three steps. The first step estimates the difference between industry exports/imports via the following equation: 


$$
\frac{\mathrm{yq}-\sum \mathrm{y} \boldsymbol{\theta}-\mathrm{Yh}}{\mathrm{q}}=\mathrm{x}-\mathrm{m}
$$

where: $\quad Y=$ total personal income

$\mathrm{y}=$ personal income by industry

$q=$ coefficient relating earnings in dollars to output in industry $\mathrm{i}$

$a=$ coefficient relating the output of industry $i$ delivered to industry $\mathrm{j}$ per dollar of earnings in industry $\mathrm{j}$

$\mathrm{h}=$ income coefficient of household demand for an industry's product

$x=$ net industry exports in earning ter ms

$m=$ net industry imports in earnings terms

Each industry's earnings is multiplied by an output-per-earnings coefficient which converts earnings to an estimate of gross output. The expected use of each output by all 16 sectors of the economy is subtracted from gross output. Household final demand for the product (as estimated from total income levels) is then subtracted from net output. The result is divided by the original output coefficient to return the data to an earnings base. The sign of the resultant earnings determines whether it is net export or import related. Although the " $\mathrm{q}$," " $\mathrm{h}$ " vectors, and the " $\mathrm{a}$ " matrix are constructed from national I-O transaction tables, the model differentiates the local economy from the nation through the use of the local earnings mix.

The model uses the industry export/import data as input to equations which estimate regional multipliers. Separate multipliers are estimated for imports and exports with the regional summations of data output from equation [7]:

$$
\begin{aligned}
& \mathrm{k}_{0}=\frac{\mathrm{Y}}{\mathrm{X}+\mathrm{M}} \\
& \mathrm{k}_{00}=\frac{\mathrm{Y}}{\mathrm{X}}-1
\end{aligned}
$$

where: $k=a$ multiplier

$$
\begin{aligned}
& O=\text { exports } \\
& O O=\text { imports } \\
& Y=\text { total output } \\
& \mathrm{X}=\text { tntal net exports in earnings terms } \\
& \mathrm{M}=\text { total net imports in earnings terms }
\end{aligned}
$$

These regional multipliers are then used to calculate industry-specific multipliers through the following relationships:

$$
\begin{aligned}
& k_{x}=\frac{x}{y}\left(k_{0}-1\right)+1 \\
& k_{m}=\frac{m}{M}\left(k_{00}-1\right)+1
\end{aligned}
$$


These equations separate the effects of an exogenous change in the regional economy into primary and secondary effects, where $\mathrm{x}$ or $\mathrm{m}$ is the primary effect and $\mathrm{k}$ is the secondary effect.

\subsubsection{Methodological Observations}

There are several characteristics of the EAA model that limit its usefulness for assessing energy/employment impacts. First, the model is not a perfect substitute for a regionspecific I-O analysis because it bases import/export estimates on national I-O relationships. Second, since the multipliers are based on relationships of a single accounting period, they are valid only for small changes in industry earnings. For large changes, it would be necessary to input new earnings levels and allow the model to calculate a multiplier based on a revised flow of exports, imports, and consumption levels. Additionally, large exogenous changes in an economy can alter the interindustry structure of the economy through the creation of forward linkages.

The model produces multipliers by industrial sector but does not permit insight into a determination of the disaggregated sectoral distribution of the total multiplier. A qualitative assessment can be obtained by comparing EAA results with the interindustry linkages detailed in the regionalized national I-O Table. With regard to industrial detail, the model's highly aggregated sectoring scheme is not completely consistent with the scope of the research intended for the present project. A more detailed sectoring scheme may be achieved by using model outputs as an intermediate control total. Because these control totals are reported in earnings terms, they can be allocated to smaller aggregations by proportionately distributing the control totals on the basis of detailed sectoral earnings data such as those reported in County Business Patterns [12].

For the purposes of this research, the model's earnings multipliers need to be transformed into employment terms. This can be accomplished through the use of local earnings per employee ratios. A priori, it can be expected that the correspondence between carnings and employment is reasonably close. For example, changes in employment would be more closely connected to changes in earnings than to changes in output. Operationally, it would seem that applying earnings-to-employee ratios to the output of equation ( 1 ) would be a reasonable point at which to modify the normal model outputs.

Another model limitation concerns the following sectors: Finance, Insurance, and Real Estate; Federal Government; and State and Local Government. The multipliers for these industries are heavily dependent upon assumptions that may not reflect reality. Federal Government is assumed to be $100 \%$ export to any region while the other two sectors are always assumed to be $100 \%$ domestic. The assumption that $100 \%$ of all government finance, insurance, and real estate activities are endogenous to a region seems to be somewhat questionable, and may be particularly significant in examining solar energy development, where nonlocal financing may exert significant impacts.

\subsubsection{The Regional Industrial Multiplier System (RIMS)}

RIMS was developed by the Bureau of Economic Analysis in the Department of Commerce. The model generates multipliers for local regions for as many as 478 industrial sectors. The model is currently operational, formally documented, and has been used in several independent analyses. 


\subsubsection{Model Overview}

RIMS multipliers are derived from the production relationships listed in the 1967 BEA National I-O Table.* Regional production relationships are approximated by utilizing County Business Patterns data to modify the national matrix coefficients [12]. The national matrix can be adjusted to reflect county-level conditions in two ways. First, industries not located in the local region are excluded from the matrix. Second, location quotients based on earnings data are used to estimate regional production shares in the remaining industries. National coefficients, modified in the preceding manner, are then assumed to be the direct requirement coefficients of a local I-O table. The direct component of a RIMS multiplier is extracted from these regionalized columns by summing the supplying industry's direct requirement coefficients.

The indirect component of the multiplier is estimated econometrically by specifying this component as a function of the direct compnnent. The data base for the indircet component is derived from local $\mathrm{I}-\mathrm{O}$ studies. This estimation also incorporates data describing a region's economic size and industrial structure.

The multipliers ultimately developed from this procedure are for gross output. For these to be useful in the present research, employment multipliers must be derived from the gross output multipliers. This is accomplished in RIMS by a two-step process. First, national earnings/gross output ratios are multiplied by the regional gross output multipliers to derive earnings multipliers. The earnings multipliers are then multiplied by regional employee/earnings ratios to estimate regional employment multipliers.

\subsubsection{Methodological Observations}

There are several advantages of the RIMS model. First, since the multipliers are derived from the BEA National I-O Table, they can be very specific with respect to industrial sector. This allows for derivation of multipliers that are very alosely matchod to the industrial sector of interest. Second, these multipliers are available at useful levels of geographical detail (e.g., SMSAs, BEA Economic Areas, and States). Third, multipliers are estimated by a technique using data describing the local economy, which builds some local economic idiosyncrasy into a given multiplier. Fourth, based on validations performed by the RIMS staff, the multipliers produced by the RIMS procedure.appear similar to multipliers developed from survey techniques [11]. Finally, RIMS multipliers are readily available and will not make undue demands on project resources.

RIMS multipliers have disadvantages, however, that stem from theoretical concerns associated with estimating the indirect component of the multiplier. First, the RIMS technique estimates the indirect component by regressing the direct oomponent (among other variables) on the indirect component. As a result, errors made in estimating the direct component will be contained in the estimate of the total multiplier. The possibility for error in estimating the direct component is not insignificant, since the RIMS technique (1) assumes that national production relationships apply locally and (2)

*Efforts are underway to update the I-O Table to 1972; however, it is not expected that the updated version will be available for use during FY79. 
uses location quotients to estimate local production shares. Another troublesome feature of the indirect component estimation is the "manufacturing proportion of total nongovernment earnings" variable used in the regression estimation. This variable is specified as being directly related to the dependent variable but enters the regression with a negative sign. This result is counter to economic intuition. Economic diversity and interdependence would be expected to increase directly with increased manufacturing activity, which would result in larger multipliers. This relationship is not portrayed in the RIMS results.

\subsubsection{EAA and RIMS Comparison}

EAA and RIMS are similar in several respects. Both models are based on national I-O relationships-RIMS on the 478-sector 1967 table and EEA on the 90-sector 1971 table constructed by BEA. Both models provide estimates of multipliers for counties. Both models use local data to estimate local aspects of production phenomena and both produce earnings multipliers. In each case, these earnings multipliers can be transf ormed into employment multipliers. These multipliers are static in nature with no attempt made to distribute the exogenous change over time. Both models are multiregional, neither is interregional, and both are currently operational.

There are important differences between the two models. The ability to report findings at a reasonable level of industrial detail is important in this research. In this regard, RIMS offers far greater detail than EAA. RIMS can also break out energy sectors more distinctly than can EAA. Both procedures can be used to estimate multipliers at the county level, but EAA methodology would appear to produce more accurate multipliers at that level due to the extensive use of local data. RIMS' multipliers appear more accurate when several county results are aggregated to a larger unit such as an SMSA. The RIMS employment multiplier estimation uses national data to derive local industry estimates of earnings. EAA derives earnings multipliers somewhat more directly but presently has only the potential, not the capability, for estimating employment multipliers. The RIMS model is fully documented while EAA is only partially documented.

The preceding evaluation of interindustry multiplier models indicates that RIMS is most appropriate for the purposes of this research. The current employment estimation capability of the model along with the industrial detail it offers override the EAA benefits of county-level estimation and more pervasive use of region-specific data. In addition, RIMS documentation and previous use will facilitate the analysis.

\subsection{INTERREGIONAL MODELS}

In order to evaluate the labor market implications of developing solar energy, it is necessary to consider the interregional impact of specified solar energy market penetration estimates. This requires an estimation of impacts that occur in the area of the development as well as the impacts that occur in areas that supply inputs to the actual development area. These interregional impacts can be estimated with a model that links developments in one region with the industrial fabric of the remainder of the economy. 


\subsubsection{The Multiregion Multi-industry (MRMI) Model}

The MRMI model is based on industrial location analysis and is capable of analyzing the interregional effects of a development scenario. The model is well documented and has been used in several applications. Although the model provides comprehensive analysis of many economic relationships, discussion focuses on employment estimation procedures.

\subsubsection{Model Overview}

The MRMI modeling process begins by estimaling llte parameters of a general industrial location equation used to determine the change-in-output of industry $i$, region $j$, period $t$. The general regional change-in-output equation can be specified as a function of any set of the following variables*: the transport cost of an input or output; annuml eurnings per worker in labor sector i; value of land per acre; output level of industry i; equipment purchases by equipment sector $i$; population density; output of industry $k$, a Inajor purchaser of industry i's output; and the output of industry $\mathrm{k}$, a major supplier to industry i. Change-in-output data derived from the former equation as well as data on industry $i$, output level in $t-1$, industry $k$, and equipment purchases in $t-1$ are used to estimate the change in employment in labor sector $i$, region $j$, period $t$. A generalized flow chart of the model is presented in Figure 5-1.

As implied in the specification, forecasts are developed recursively. Period t-l data are used to forecast variables in period $t$ and these variables are used to forecast data for year $\mathrm{t}+\mathrm{l}$. Forecasts of the location of new plants are made with a threshold constraint a forecast output must exceed a previuusly deteininined output level in order for the model to allow the industrial location change. The threshold level is defined with plantsize data where the output level of the plant size having the largest number of reporting units is taken as the threshold level. In addition, since the model makes the assumption of no abrupt changes in a region, certain arbitrary limits are placed on changes in output and employment.

The forecasts of regional data are controlled by national forecasts. Unless these controls are used, the sum of regional data may be unreasonable. In order that the regional and national models are made comparable, the national data are allocated by converting the regional variables to regional shares of the national totals. The national model used is INFORUM, which is a dynamic I-O model that forecasts national economic data under various assumptions about final demand spending [6].

\subsubsection{Methodological Observations}

Probably the most important limitation of the MRMI model is the data used to construct the model. In general, 1965-1966 data were used for parameter estimation. Recently, some 1970 data were incorporated into the model. Using such cross-section data forces the assumption that parameters do not change over time, which is acceptable in the short

*All independent variables are lagged one period. 


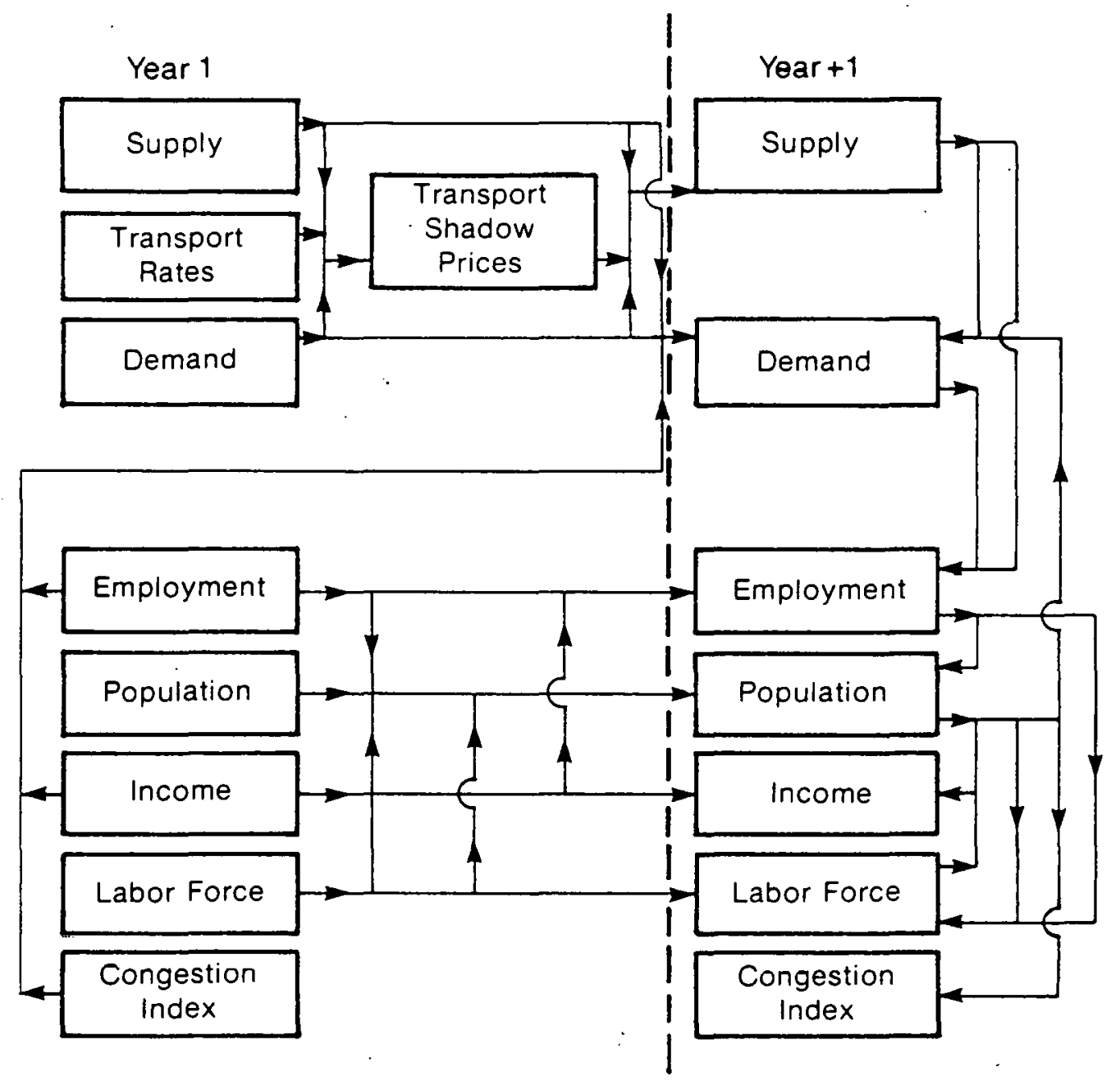

Figure 5-1. Simplified Flow Chart of Multiregional, Multi-industry Forecasting Model 
run. However, at the time the model would be implemented in this research, the data would be at least eight or nine years old.

The MRMI model utilizes a considerable amount of data from the INFORUM national model. MRMI regional data are shares of the national data generated by INFORUM. In addition, INFORUM data describing interindustry relationships are used to estimate demand. This reliance on national data may be inappropriate at the county level where production functions and product mix may differ significantly from the national average. The use of national data as control totals means that the accuracy of the regional allocations depend on the validity of the national data.

Another area of concern is the predictive accuracy achieved in estimating employment for a number of sectors that were indieated in a recent study by petcrscn to be important in the development of solar energy.* These sectors, alnng with the summary statistics** describing the MRMI estimation results are listed in Table 5-1. The data in this table are presented as a means of describing the implications of MRMIs predictive ability for specific sectors expected to be significantly impacted by solar energy develnpment.

Columns 1 and 2 of the table indicate Petersen's sector titles and corresponding SIC codes for sectors expected to experience the greatest impact from development of solar space and water heating technologies. Petersen's estimates of the number of jobs affected in these sectors are reported in Column 3. MRMI sectors most closely associated with the sectoring scheme utilized by Petersen are indicated in Column 4. The coefficients of determination achieved by MRMI estimation for each sector are reported in Column 5. .

Petersen's' study indicates that the largest employment change occurs in the Electric Utilities sector where the MRMI coefficient of determination is only 0.30 . The second largest change occurs in the Blast Furnace and Basic Steel Products sector, where the coefficient of determination is 0,54 . This suggests that the nitpint of the model must be interpreted carefully in those sectors where MRMI predictive ability is weak.

Although several important criticisms have been made about the MR.MI mniel, it has several aspects that are useful for research purposes. First, the detailed sectoring scheme enables the analysis to focus on fairly specific sectors of the economy. Second, the model provides output at the county level. Finally, the model's interregional nature permits the analysis to assess the impact of a solar energy scenario regardless of the area in which the impact occurs. Even though the absolute levels of employment forecast by the model may not be precise, the model can provide a general indication of the relative regional shares of an impact.

*Petersen's method involved augmenting a National I-O Table, postulating the implementation of a SHACOB scenario and estimating the total employment impact of that scenario by deriving the matrix of direct and indirect requirements [15].

**Summary statistics are the coefficient of determination and the " $t$ " statistic. 
Table 5-1. COMPARISON OF MRMI MODEL WITH PETERSEN'S STUDY

\begin{tabular}{|c|c|c|c|c|}
\hline \multicolumn{3}{|c|}{ Petersen's Study ${ }^{\mathrm{a}}$} & \multicolumn{2}{|c|}{ MRMI Model - } \\
\hline . & SIC Codes & $\begin{array}{l}\text { Affected } \\
\text { Number } \\
\text { Jobs }\end{array}$ & $\begin{array}{c}\text { Sectors Most } \\
\text { Closely } \\
\text { Related to } \\
\text { Petersen's } \\
\text { SIC Codes }\end{array}$ & $\begin{array}{c}\mathrm{R}^{2} \text { for Change } \\
\text { in Employment } \\
\text { Equation }\end{array}$ \\
\hline Copper Rolling and Drawing & 3351 & 1643 & $3331,51,62$ & 0.71 \\
\hline Primary Copper Metals & 3331 & 293 & $3331,51,62$ & 0.71 \\
\hline Copper Ore Mining & 0102 & 602 & $0102-5,8,9$ & 0.77 \\
\hline Electric Utilities & 491 , pt 493 & 6360 & 491,4931 & 0.30 \\
\hline Aluminum Rolling and Drawing & 3352 & 794 & $3334,52,61$ & 0.69 \\
\hline Seientific and Controlling Instruments & $381,2,7$ & 1836 & $381,2,4,7$ & 0.64 \\
\hline Primary Aluminum & 3334 & 236 & $3334,52,61$ & 0.69 \\
\hline Blast Furnaces and Basic Steel Products & 331 & 3845 & $331,2,9$ & 0.54 \\
\hline Iron Ore Mining & 101,106 & 97 & 101,106 & 0.71 \\
\hline Other Primary and Secondary Nonferrous & $3332,3,9$ & & $3332,3,9,334$ & \\
\hline Materials & and 334 & 174 & $3356,7,3369$ & 0.42 \\
\hline Glass & $321,2,3$ & 680 & $321,2,3$ & 0.48 \\
\hline Millwork, Plywcod, end Other Wood Products & $243,4,9$ & 1262 & $\begin{array}{c}24 \text { exc. } 244 ; \\
244\end{array}$ & $\begin{array}{l}0.49 \\
0.66\end{array}$ \\
\hline Plastic Products & 307 & 1856 & 30 & 0.66 \\
\hline Coal Mining & 11,12 & 589 & 11,12 & 0.22 \\
\hline General Industry Machinery & 356 & 1269 & 356 & 0.62 \\
\hline Other Nonferrous Metal Ore Mining & $103,4,5$ & & $0102-5,8,9$ & 0.77 \\
\hline & $6,7,8,9$ & 78 & 101,6 & 0.71 \\
\hline Cement, Clay, and Concrete Products & $324,5,7$ & 1094 & $324-9$ & 0.67 \\
\hline Plastic Materials and Synthetic Rubber & 2821,2 & 247 & 282 & 0.89 \\
\hline
\end{tabular}

a [15] 


\subsubsection{The MULTIREGION Model}

The MULTIREGION model was created by the staff of Oak Ridge National Laboratories (ORNL). MULTIREGION was developed for the purpose of analyzing public policy options in a regional economic framework. The model is used to forecast and simulate regional demographic and economic activity in terms of population and employment within the context of given national control totals.

\subsubsection{Model Overview}

As noted in Section 4.5, the model is built upon the notion that a region's economy should be viewed as a labor market. In this context, it is necessary to model phenomena affecting labor supply and labor demand. Labor supply is viewed as a function of changes in mortality, fertility, migration, and labor force participation. Labor demand is a function of locational advantages. Labor market equllibrating forces are modeled by iterating the labor demand and labor supply modules until they are in agreement.

The data used for estimation purposes are drawn from the Census of Population socioeconomic accounts. The unit of analysis is defined as a BEA economic area-173 mutually exclusive functional economic units that cover the total land area and population of the United States. MULTIREGION provides data on employment by 37 industry groups, population by 32 age and sex cohorts, and labor force by 16 age and sex cohorts, for the United States as a whole (exogenously given), and each of $173 \mathrm{BEA}$ economic areas at five-year intervals. In addition, MULTIREGION can be used to disaggregate BEA forecasts to the county level.

The process for producing employment forecasts follows the iterative procedure diagrammed in Figure 5-2. In order to obtain a perspective on the appropriateness of this process, the components of a representative stage will be considered. Figure 5-3 diagrams the major components of a stage. The computational procedure for a stage is as follows.

(1) Trial population values are computed where population "this period" is assumed to equal population "last period," plus births, minus deaths, plus immigrants, minus emigrants.

(2) Trial labor supply values are computed by multiplying the estimated population by labor participation rates.

(3) Trial labor demand values are computed as the sum of forecasted agriculture and mining employment, the region's share of forecasted national manufacturing employment, and local service employment.

(4) Trial labor market conditions (e.g., unemployment rates) are computed by bringing together trial labor supply and labor demand values.

(5) Final labor market conditions are computed by repeating Steps 1 through 4 until consistent supply and demand estimates are achieved.

(6) At this point, regional and interregional conditions are recompiled and the computations for the next five-year step begins. 
Stage 1

$\tilde{\omega}$

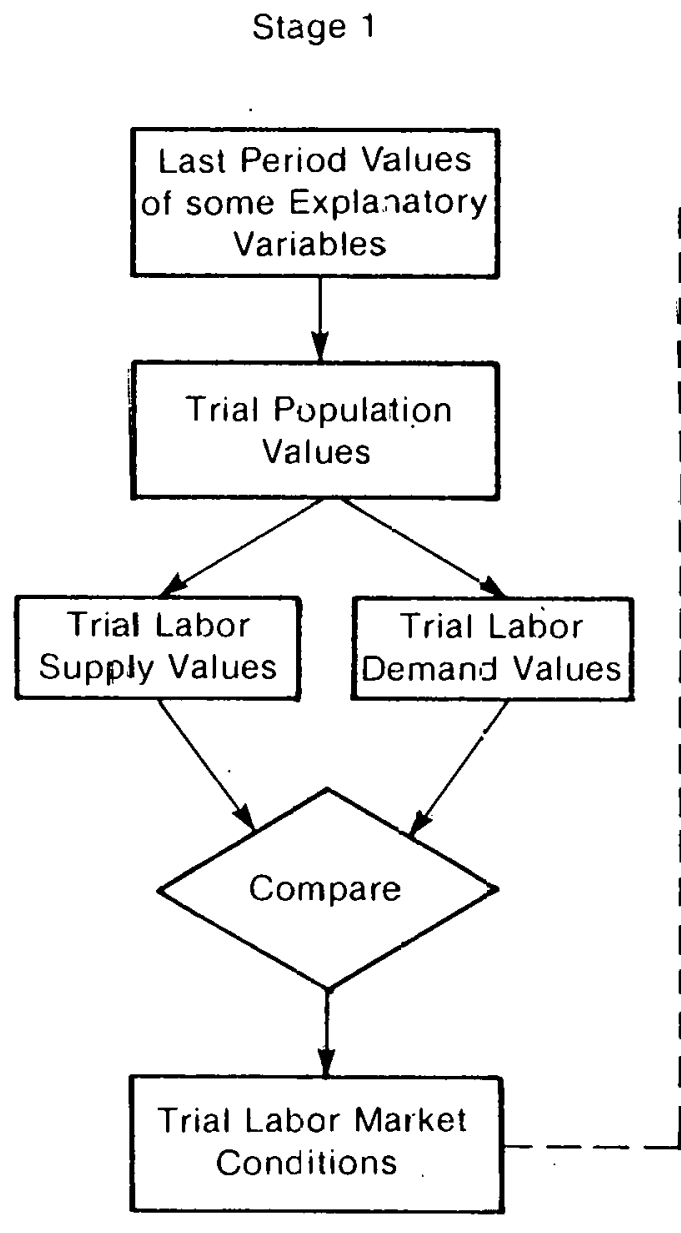

Stage 2

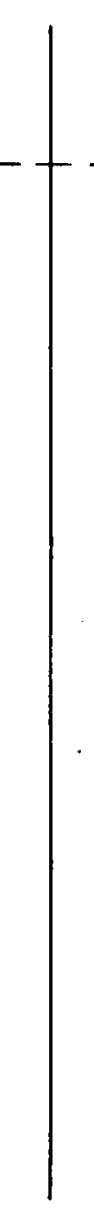

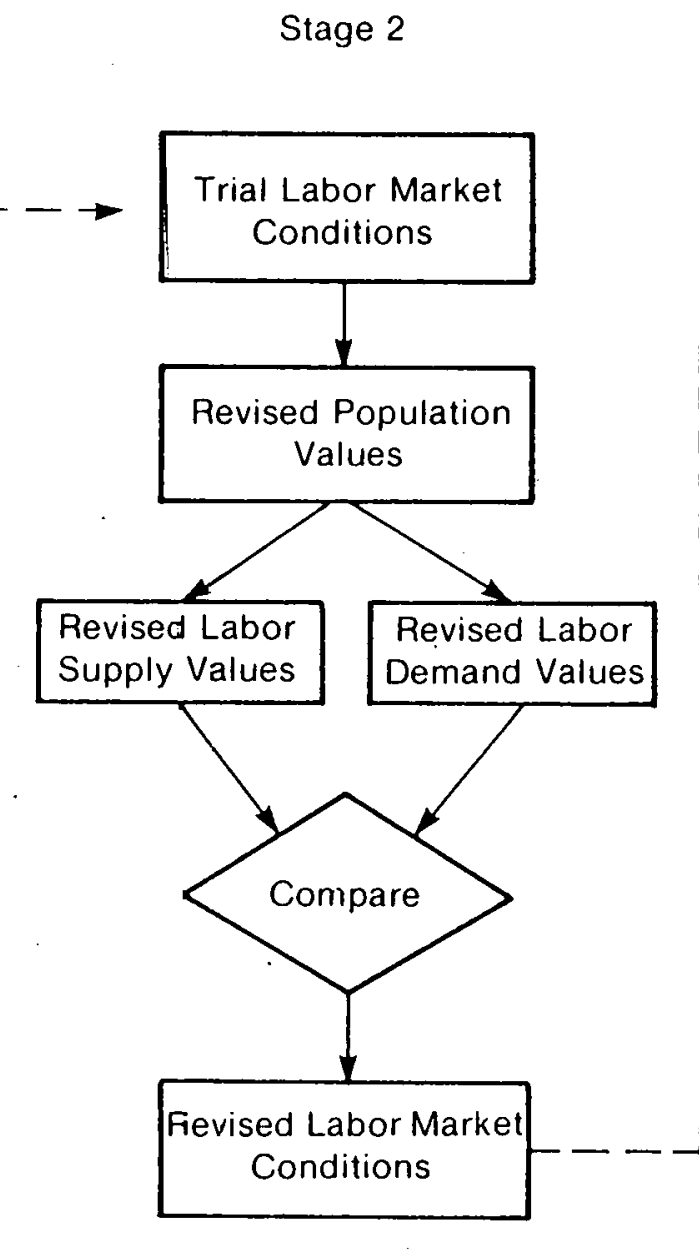
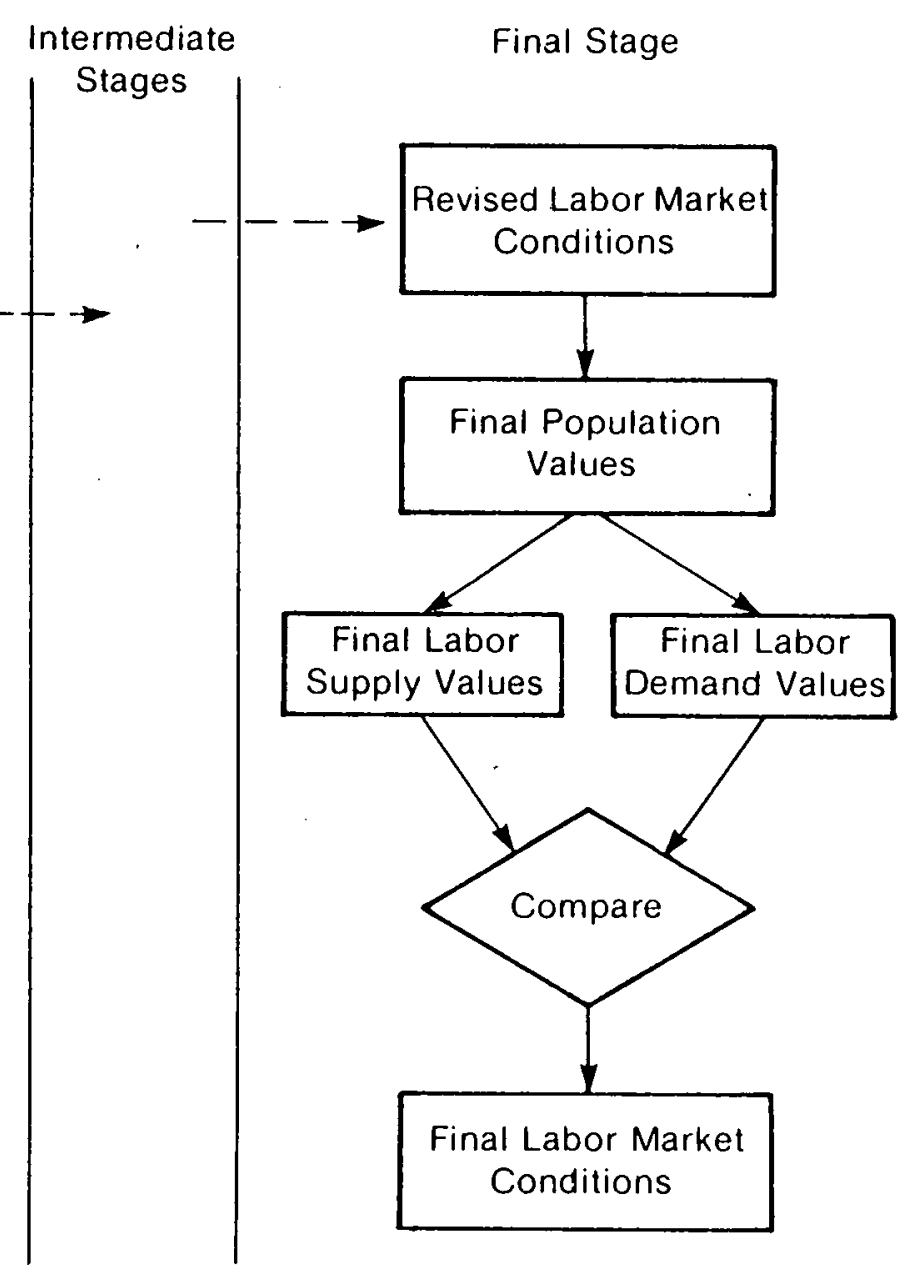

Figure 5-2. MULTIREGION Computations during a Five-YearTime Step 


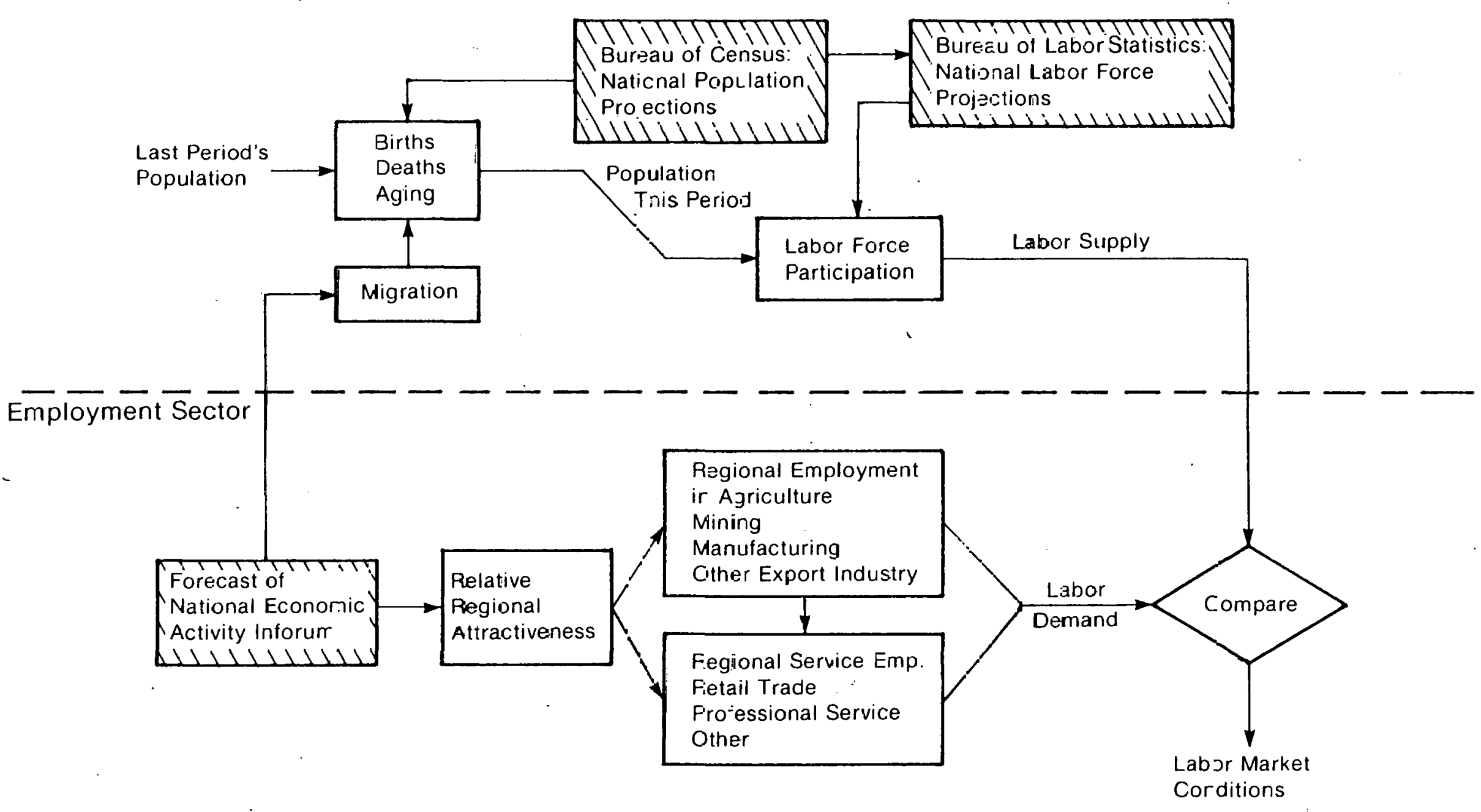

Note: Predeterm neJ nationa values indicated by shaded boxes.

Figure 5-3. MULTIREGION within the Context of a National Economy 
The most relevant aspect of the procedure for this research is Step 3, where manufacturing and service employment is determined. The manufacturing equations are specified with variables which model regional attractiveness for industrial location. The service equations are similarly specified. The components of Steps 2 through 6, which affect the model's employment estimation capabilities, are considered in more depth below.

The model's output is controlled in several ways. The model uses the INFORUM national model to ensure that the individual forecasts add to reasonable national totals. In addition, the model forces forecasts to conform to interregional balances, floors and ceilings, and trends in the residual around empirically fitted relationships. For example, employment and unemployment rates cannot be negative and consistent deviations from a fitted regression line can be added to or subtracted from a basic forecast to improve overall forecast accuracy.

\subsubsection{Methodological Observations}

In general, the reported summary statistics indicate that the model produces reasonable estimates of manufacturing and service employment. In large measure this success can be attributed to an independent variable that measures the level of employment in a given sector, lagged one period. This variable, defined as the initial condition variable, virtually swamps the contribution of any other variable that may be used. The variable is not inappropriate, however, as it is true that any near-term industrial location configuration is a function of past location decisions and the inertia embodied in the resulting distribution of industry. Given the tremendous amounts of human and material capital investment associated with industrial location and relocation, the "initial conditions" variable seems intuitively appropriate (although it may be inappropriate for projecting long-term employment patterns).

An important consideration is the level of industrial disaggregation that a model provides. MULTIREGION breaks manufacturing employment into 14 sectors, which is quite aggregated for the present research. To achieve the disaggregation needed, it would be necessary to use MULTIREGION data as control totals and distribute those data by proportioning or a similar technique. In comparison, the service sector offers reasonable disaggregation by dividing this group into 16 sectors. Public utilities are aggregated into one sector, which limits the ability to focus on specific utilities.

Multiplier estimation is very important for this research. The multiplier estimation technique used by MULTIREGION is a relatively sophisticated version of economic base analysis. Most economic base analyses express service employment as a simple and direct function of export employment. MULTIREGION expands this approach by relating service employment to phenomena which determine the regional ability to export and to serve a local population. The resulting specification is one which models the relative attractiveness of a region as a service area. The variables used in this scheme are of several generic types: initial conditions variables, market size variables, local market quality variables, and variables indicating special regional circumstances.

The most important variable used in the estimation is the initial conditions variable. This variable accounts for most of the explanatory power of the equations. The market size and market quality variables, while making a statistically significant contribution, are of secondary importance. The coefficients of determination are above 0.98 for this specification. Although economic base analysis is unsatisfactory in its simpler forms, MULTIREGION's sophisticated approach seems to have produced useful results. 
Summarizing, MULTIREGION has several desirable and undesirable aspects in relation to this research. On the positive side, MULTIREGION equations have strong summary statistics and appear to have relatively strong forecasting capabilities. This success probably stems from an appropriate specification scheme. In addition, the model is well documented and can be used to estimate interregional impacts. The model's major limitation is the highly aggregated sectoring scheme. Also, the heavy reliance of both manufacturing and service equations on the "initial conditions" variables apparently overwhelms the explanatory contribution made by other variables which, for individual regional forecasts, may be very important. Finally, MULTIREGION, like MRMI, relies on national control totals and somewhat arbitrary means to ensure that forecasts are in line with intuitive expectations.

\subsubsection{MRMI and MULTIREGION Comparison}

It is not clear from the examination of the model's structure which model will be best suited for analyzing the employment impact of solar energy development. Both models have strengths and weaknesses. The MRMI sectoring scheme offers considerable detail, but some of the summary statistics are disconcerting. MULTIREGION, on the other hand, has a sectoring scheme which is highly aggregated, but the model's summary statistics are encouraging. In order to facilitate choosing between these two models, the models' forecasting accuracies are compared in the next section. 


\section{SECTION 6.0}

\section{EMPIRICAL COMPARISON OF MODEL OUTPUT}

In order to interpret the results of data output from the regional and interregional models, it is useful to compare the output of these procedures with data generated in area-specific multiplier analysis (regional model) and published employment data (interregional models). The purpose of this comparative exercise is to provide a general indication of the "accuracy" of the output provided by the generalized models. In conducting the model comparisons, it is important to keep in mind that each data source of ten uses different assumptions and conventions or measures different quantites. These comparisons should be viewed only as general indications of the "accuracy" achieved by the more generalized models.

\subsection{THE REGIONAL INTERINDUSTRY MULTIPLIER MODELS}

The area-specific models chosen to assess the accuracy achieved by the general multiplier model are those developed for a nine-county area in northern California [16] and two models of Colorado regions [17, 18]. All models are of the I-O type and are based, at least partially, on survey data. In addition, the researchers who constructed the models were familiar with local secondary data bases and could draw on them to supplement the primary data. The use of these data bases suggests that these models represent "real world" interactions as accurately as can be expected.

\subsubsection{The California Model}

The University of California Cooperative Extension Service has developed a 1974 version of an I-O model for the San Francisco region [16]. The region is divided into nine counties: Marin, Sonoma, Napa, Solano, Alameda, Contra Costa, Santa Clara, San Mateo, and San Francisco. The model has 52 processing sectors and three final demand sectors. Household expenditures and incomes are endogenous.

The method for developing the 1974 model relies on two main data sources: the 1967 BEA National I-O Table, and a 1971 update of the 1967 National Table.* The 1974 model incorporates both survey and secondary data. The most important use of primary data was in the formation of regional exports and imports.

\subsubsection{The Colorado Region Models}

Dr. Joseph Weber has constructed a 1974 I-O model for a nine-county area in northwestern Colorado [17]. The nine counties are Delta, Eagle, Garfield, Mesa, Moffat, Montrose, Pitkin, Rio Blanco, and Routt. The region is defined to also include the Somerset coal area of Gunnison County. The model is divided into 33 processing sectors

*The method used to update the 1967 National I-O Table is explained by McMenamin and Haring [19]. 
and 13 final demand sectors. This sectoring scheme places emphasis on agriculture, mining, manufacturing, public utilities, and government sectors.

The data used to estimate the matrix elements were gathered from a wide variety of sources. Primary data were obtained from economic producers and government agencies. A relatively high proportion of primary data was obtained from the extractive, manufacturing, utilities, finance, medical care, and tax-supported sectors, Moderate amounts of primary data were secured from the agricultural services, construction and insurance, and real estate sectors. Very little primary data were obtained from the trade and service sectors.

Another model of the Colorado region was developed at Colorado State University [18]. This model is a $1970 \mathrm{I}-\mathrm{O}$ model for the State of Colorado. The model was developed "to analyze the relationships between the economic sectors of the state eronnomy and to relate economic activity in the state to the requirements placed on the state's water resources" [17]. The model divides the economy into 28 processing sectors, three finaldemand sectors, and four final-payments sectors. Household purchases are endogenous in the model and multipliers are estimated through matrix inversion.

A variety of data was used to estimate the elements of the transactions table. The most important of these was a $60 \%$ sample of Colorado industries that was used as the basis for estimating interindustry flows. Total gross output estimates were used as control totals to ensure the reasonableness and consistency of the primary data. The total gross output estimates were extracted from a variety of secondary sources reporting on Colorado state-specific industries.

\subsection{REGIONAL INTERINDUSTRY MULTIPLIER MODEL COMPARISONS}

The procedure for comparing multiplier estimates of the RIMS model with similar estimates of the local area models has several steps. First, the sectoring schemes of the local area models and the RIMS model are made as comparable as possible. In the case of the California and western Colorado models, this step was achieved by aggregating the local area models' sectors to match RIMS sectors. Output data from the local area studies' transaction tables were used as weights for the aggregation. Since this comparison relies on published data, all sectors of the local area models could not be made comparable to RIMS sectors. This stems from differences in the sector definitions used in the separate models. In the case of the Colorado state model, the sectoring scheme is quite dissimilar to that used in RIMS. To provide some rough comparisons, unweighted averages of RIMS sectoral multipliers were used to derive multiplier estimates for sectors that reasonably approximated the Colorado state sectors. As a result, the comparisons can provide only gross indications of the "accuracy" of RIMS multipliers.

The second step in the comparison procedure was to subtract local area multipliers from RIMS multipliers. These data indicated the amount of disparity between the two estimates and whether the RIMS estimates were high or low. The third step expressed the differential estimate as a proportion of the RIMS estimate, which gives a gross indication of the extent of error to be expected when using RIMS multipliers. The data derived from the comparison procedure are presented in Tables 6-1, 6-2, and 6-3.

It should be pointed out that the comparisons in this exercise are made among output multipliers. The focus of the ultimate research will be on employment impacts. Consequently, a constant relationship between output and employment is assumed. 
Table 6-1. SECTOR AND MULTIPLIER (k) COMPARISON: SAN FRANCISCO AREA (SF), RIMS

\begin{tabular}{|c|c|c|c|c|c|c|}
\hline Sector & SIC ${ }^{\text {San Frane }}$ & $k$ & SIC & k & $\begin{array}{c}\text { RIMS } \\
\text { minus } \\
\text { SF }\end{array}$ & $\frac{\text { RIMS-SF }}{\text { RIMS }}$ \\
\hline Lumber \& Wood Prod. & 24 & & 244,25 & 2.99 & 0.62 & 0.21 \\
\hline Furniture & 25 & & & & & \\
\hline Paper \& Allied Prod. & 26 & 2.26 & 26 & 2.90 & 0.64 & 0.22 \\
\hline Printing and Publishing & 27 & 3.22 & 27 & 3.29 & 0.07 & 0.02 \\
\hline $\begin{array}{l}\text { Chemicals, Plastics \& } \\
\text { Synthetics }\end{array}$ & 28 & 2.46 & 28 & 2.90 & 0.44 & 0.15 \\
\hline $\begin{array}{l}\text { Petroleum Refining \& } \\
\text { Related Industries }\end{array}$ & 29 & 1.92 & 29 & 2.22 & 0.30 & 0.13 \\
\hline Stone \& Clay Prod. & 32 & 2.30 & 32 & 3.24 & 0.94 & 0.29 \\
\hline $\begin{array}{l}\text { Primary Iron, Steel } \\
\text { Mfg. }\end{array}$ & 331 & & & & & \\
\hline $\begin{array}{l}\text { Primary Nonferrous } \\
\text { Metal Mfg. }\end{array}$ & $333-336$ & 1.78 & 33 & 2.75 & 0.97 & 0.35 \\
\hline Metal Containers & 341 & & & & & \\
\hline $\begin{array}{l}\text { Fabricated Structural } \\
\text { Metal Products }\end{array}$ & 343,344 & & & & & \\
\hline Screw Machine Prod. & 345,346 & 2.47 & 34 & 2.87 & 0.40 & 0.14 \\
\hline $\begin{array}{l}\text { Other Fabricated } \\
\text { Metal Products }\end{array}$ & $\begin{array}{l}342,347-349 \\
351\end{array}$ & & & $\cdot$ & & \\
\hline $\begin{array}{l}\text { Construction \& Materi- } \\
\text { als Handling }\end{array}$ & 353 & & & & & \\
\hline $\begin{array}{l}\text { Metal Working Special } \\
\text { Industrial Equip. }\end{array}$ & 354,355 & & & & & \\
\hline $\begin{array}{l}\text { General Industrial } \\
\text { Machinery }\end{array}$ & 356,359 & 2.32 & 35 & 3.11 & 0.79 & 0.25 \\
\hline $\begin{array}{l}\text { Office, Computing } \\
\text { Machinery }\end{array}$ & 357 & & & & & \\
\hline $\begin{array}{l}\text { Service Industry } \\
\text { Machines }\end{array}$ & 358 & & & & & \\
\hline Electric Trans. Equip. & 361,362 & & & & & \\
\hline $\begin{array}{l}\text { Electric Lighting } \\
\text { Equip. }\end{array}$ & 363,364 & 2.49 & 36 & 3.27 & 0.78 & 0.24 \\
\hline Radio, T.V. Com. Equip. & 365,366 & & & & & \\
\hline $\begin{array}{l}\text { Electronic Components } \\
\text { \& Equipment }\end{array}$ & 367,369 & & & & & \\
\hline Motor Vehicles \& Equip. & 371 & & & & & \\
\hline Aircraft \& Parts & 372 & 2.66 & 37 & 2.75 & 0.09 & 0.03 \\
\hline Other Transport Equip. & $373,375,379)$ & & & & & \\
\hline $\begin{array}{l}\text { Professional and Scien- } \\
\text { tific Equip. }\end{array}$ & 38 & 2.42 & $19,38,39$ & 2.94 & 0.52 & 0.18 \\
\hline Misc. Manufacturing & 39 & & & & & \\
\hline 'Iransportation & $40-47$ & & & & & \\
\hline Communications & 48 & 2.88 & $40-49$ & 2.74 & -0.14 & 0.05 \\
\hline Utilities & 49 & & & & & \\
\hline Trade & $50-59$ & 2.84 & $50-59$ & 3.28 & -0.44 & 0.03 \\
\hline Banking & $60,61,62,63\}$ & 2.64 & $60-67$ & 2.51 & -0.13 & 0.05 \\
\hline Real Estate & 65,66 & & & & & \\
\hline Personal Services & 70,72 & & & & & \\
\hline Misc. Business Services & $73,81,89$ & 3.21 & $70-89$ & 3.37 & 0.16 & 0.05 \\
\hline Auto Repair \& Amusements & 75,78 & & & & & \\
\hline Arithmetic Mean & & & & & & 0.16 \\
\hline
\end{tabular}


(ii

Table 6-2. SECTOR AND MULTIPLIER (k) COMPARISON: WESTERN COLORADO (WC), RIMS

\begin{tabular}{|c|c|c|c|c|c|c|}
\hline \multirow[b]{2}{*}{ Sector } & \multicolumn{2}{|c|}{ Western Colorado } & \multicolumn{2}{|c|}{ RIMS } & \multirow{2}{*}{$\begin{array}{l}\text { RIMS } \\
\text { minus } \\
\text { WC }\end{array}$} & \multirow{2}{*}{$\frac{\text { RIMS-WS }}{\text { RIMS }}$} \\
\hline & SIC & $\mathrm{k}$ & SIC & $\mathrm{k}$ & & \\
\hline $\begin{array}{l}\text { Metal Mining, Related } \\
\text { Services }\end{array}$ & 10 & 1.89 & 10 & 1.85 & -0.04 & 0.02 \\
\hline Coal Mining, Underground & 11 & 1.83 & $11 \& 12$ & 2.40 & 0.56 & 0.23 \\
\hline Coal Mining, Service & 12 & & & & & \\
\hline Oil and Gas Extraction & 13 & 1.34 & 13 & 1.89 & 0.55 & 0.29 \\
\hline Nonmetal Mining & 14 & 1.60 & 14 exc. 147 & 2.00 & 0.40 & 0.20 \\
\hline Construction & $15,16,17$ & 2.33 & $16,16,17$ & 2.09 & -0.23 & 0.11 \\
\hline Stone, Clay, Glass Mfg. & 32 & 1.57 & 32 & 2.28 & 0.70 & 0.31 \\
\hline Transportation & $40-42,45-47$ & & & & & \\
\hline U.S. Postal Service & 43 & & & & & \\
\hline Cummunleation & 48 & 1.94 & $40-49$ & 2.12 & 0.18 & 0.09 \\
\hline Electric \& Gas Utilities & $491-493$ & & & & & \\
\hline $\begin{array}{l}\text { Water, Sewage, Trash } \\
\text { Removal }\end{array}$ & $494-497$ & & & & & \\
\hline Wholesale Trade & 50,51 & & & & & \\
\hline $\begin{array}{l}\text { Automobile Deulers; Gus= } \\
\text { oline Service Stations }\end{array}$ & 55 & & & & & \\
\hline $\begin{array}{l}\text { Eating \& Drinking Estab. } \\
\text { Hotels, Motels, Other } \\
\text { Lodging }\end{array}$ & 58,70 & 1.90 & $50-59$ & 2.43 & 0.53 & 0.22 \\
\hline All Other Retail Trade & $\begin{array}{l}52-54,56 \\
57,59\end{array}$ & & & & & \\
\hline Finance & $\begin{array}{l}60,61,62 \\
67\end{array}$ & 1.49 & ตก-ค7 & 1.85 & 0.36 & 0.19 \\
\hline Insurance, Real Estate & 63,66 & & & & & \\
\hline Health Services & 80 & & & & & \\
\hline All Other Services & $\left.\begin{array}{l}72,73,75,76, \\
78,79,81,84 \\
86,89\end{array}\right\}$ & 1.77 & $70-89$ & 2.48 & 0,71 & 0.29 \\
\hline Arithmotic Mean & & & & & & 0.19 \\
\hline
\end{tabular}


Table 6-3. SECTOR AND MULTIPLIER (k) COMPARISON: COLORADO STATE (COLO), RIMS

\begin{tabular}{|c|c|c|c|c|c|c|}
\hline \multirow[b]{2}{*}{ Sector } & \multicolumn{2}{|l|}{ Colorado State } & \multicolumn{2}{|c|}{ RIMS } & \multirow{2}{*}{$\begin{array}{l}\text { RIMS } \\
\text { minus } \\
\text { Colo }\end{array}$} & \multirow{2}{*}{$\frac{\text { RIMS-Colo }}{\text { RIMS }}$} \\
\hline & SIC & $k$ & Sector \# & $\mathrm{k}$ & & \\
\hline $\begin{array}{l}\text { Livestock \& Livestock } \\
\text { Prod. }\end{array}$ & 02 & 3.18 & 3 & 2.83 & -0.35 & 0.12 \\
\hline Metal Mining & 10 & 2.17 & 13 & 2.10 & -0.07 & 0.03 \\
\hline Coal Mining & 1211 & 2.22 & 14 & 2.53 & 0.31 & 0.12 \\
\hline Petroleum Production & 1311,21 & 2.24 & 15 & 2.03 & -0.21 & 0.10 \\
\hline Industrial Mineral Prod. & $\left.\begin{array}{l}14 \text { (exc. } 148), \\
324,325,327\end{array}\right\}$ & 2.13 & 16,46 & 2.55 & 0.42 & 0.16 \\
\hline Mining Services & $\left.\begin{array}{l}1081,1213, \\
1381,1382,1389 \\
1481\end{array}\right\}$ & 2.23 & $\begin{array}{l}13,14,15 \\
16\end{array}$ & 2.22 & -0.01 & $\longrightarrow$ \\
\hline Food and Kindred Prod. & 20 & 2.57 & $19-34$ & 2.46 & -0.11 & 0.04 \\
\hline $\begin{array}{l}\text { Textiles, Leather, } \\
\text { Apparei }\end{array}$ & $22,23,31$ & 1.82 & 36,45 & 2.09 & 0.27 & 0.13 \\
\hline Lumber \& Wood Prod. & $\left.\begin{array}{l}24,2511,2512 \\
2519,2521\end{array}\right\}$ & 1.79 & $37,38,39$ & 2.23 & 0.44 & 0.20 \\
\hline Paper \& Allied Prod. & 26 & 1.56 & 40 & 2.26 & 0.70 & 0.31 \\
\hline Printing and Publishing & 27 & 1.93 & 41 & 2.33 & 0.40 & 0.17 \\
\hline $\begin{array}{l}\text { Chemicals, Explosives, } \\
\text { \& Rubber }\end{array}$ & $\begin{array}{l}28,30 \\
3482,3483\end{array}$ & 1.75 & 42,44 & 2.01 & 0.26 & 0.13 \\
\hline Petroleum Refining & $2911,2915,2519$ & 2.57 & 43 & 2.73 & 0.16 & 0.06 \\
\hline Primary Metal & 33 & 2.12 & 47 & 2.05 & -0.07 & 0.03 \\
\hline $\begin{array}{l}\text { Fabricated Metal, Machin- } \\
\text { ery, and Electrical }\end{array}$ & $\begin{array}{l}25,34,37 \\
35(p t), 36 \\
(p t)\end{array}$ & 1.69 & $39,48-51$ & 2.21 & 0.52 & 0.24 \\
\hline $\begin{array}{l}\text { Electronic \& Scientific } \\
\text { Prod. }\end{array}$ & $\begin{array}{l}35(p t), 36 \\
(p t), 38\end{array}$ & 1.78 & $49,50,52$ & 2.23 & 0.45 & 0.20 \\
\hline All Other Mfg. & $\left.\begin{array}{l}21,32(p t), \quad\} \\
39\end{array}\right\}$ & 2.89 & $35,46,52$ & 2.44 & -0.45 & 0.18 \\
\hline $\begin{array}{l}\text { Transportation, Communi- } \\
\text { cation, \& Utilities }\end{array}$ & $\begin{array}{l}40-42,45 \\
47-49\end{array}$ & & & & & \\
\hline $\begin{array}{l}\text { Flertrin Power Generg- } \\
\text { tion }\end{array}$ & 4911,4931 & & & & & \\
\hline $\begin{array}{l}\text { Natural Gas Distribu- } \\
\text { tion }\end{array}$ & 4924,4931 & 2.26 & 53 & 2.18 & -0.08 & 0.04 \\
\hline $\begin{array}{l}\text { Pipeline Transporta- } \\
\text { tion }\end{array}$ & $\begin{array}{l}4612,4213,4222 \\
4223\end{array}$ & & & & & \\
\hline Trade & $50-59$ & 2.65 & 54 & 2.32 & -0.33 & 0.14 \\
\hline Services & $\left.\begin{array}{l}70,72,73, \\
75,76,78-81, \\
84,86,89\end{array}\right\}$ & 2.45 & 56 & 2.58 & 0.13 & 0.05 \\
\hline Arithmetic Mean & & & & & & $0.1 \%$ \\
\hline
\end{tabular}


Data derived from the San Francisco-RIMS comparison are presented in Table 6-1. Column 1 lists the San Francisco sector numbers and titles. Column 2 lists the San Francisco sectors by SIC code, and Column 3 indicates the multipliers $(k)$ for these sectors. Columns 4 and 5 list SIC codes and multipliers reported in RIMS for the San Francisco BEA economic area. It should be noted that the RIMS area includes five counties more than is included in the San Francisco study area. As a result, the outcome of the comparison can only be considered to be suggestive of the actual relationship between RIMS and San Francisco study multipliers. The important point to notice in the data is that RIMS multipliers overstate the San Francisco study multipliers in 14 of the 16 observations. In addition, the average error proportions developed from the data suggest that RIMS multipliers overstate the San Francisco multipliers by about $16 \%$.

Data derived from the western Colorado-RIMS multiplier comparison are presented in Table 6-2. Although fewer sectors can he compared, the observations noted with the San Francisco data al'e also noled with the western Colorado data. First, in eight of the 10 observations, KIIVIS multipliers overstate the local area multipliers. Second, RIMS multipliers overstate the local area multipliers by about $19 \%$. The RIMS multipliers are reported for an area that is eight counties larger than the area covered by the western Colorado study.

Comparisons between the Colorado State and RIMS multipliers are reported in Table 6-3. The data in this table are arranged in a manner similar to the previous two tables with the exception that the RIMS sectoral multipliers are identified by sector number rather than by SIC code. This change was necessitated by the models' sectoral dissimilarities. The results of the comparison yield slightly different insights into the RIMS multiplier estimates than was noticed previously. This comparison does not indicate a consistent RIMS overestimation. The deviations are about equally divided between overestimates and underestimates. Also, the average error proportion decreased to about $12 \%$. This suggests that the accuracy of RIMS multipliers may increase and become more random as the geographic area expands.

\subsection{THE INTERREGIONAL MODELS}

The review of the structure of the MRMI and MULTIREGION models indicated that both models are potentially useful. To further aid in choosing the more appropriate model, a comparison will be made between employment data published by (1) the Regional Economic Information Service (REIS) Bureau of Economic Analysis and (2) the employment forecasts of the two models. The comparison is only intended to be suggestive of the validity of the model's forecasting capability.

In structuring the comparison procedure, it became apparent that a direct comparison of the model's forecasts and observed employment data would not be possible for several reasons. First, MRMI and MULTIREGION forecasts are published for similar yet different geographic areas. MRMI forecasts are for Standard Metropolitan Statistical Areas (SMSAs) and MULTIREGION forecasts are for Bureau of Economic Analysis economic areas (BEAs). The relationship between the areas is that, generally, BEAs include an SMSA plus additional counties in proximity to the SMSA. In the comparison, this forecast area dissimilarity was mitigated when possible by aggregating SMSAs to more closely approximate BEAs.

The second factor limiting the comparability of the forecasts involves the time elapsed between the model's parameter estimation and the forecast observed. MRMI equations 
were estimated in the late 1960s while MULTIREGION equations were estimated in the early 1970s. One would expect that the more recent data base incorporated in MULTIREGION would yield more accurate estimates for 1975. The comparison is, therefore, somewhat more demanding of the MRMI forecasts.

A third factor limiting the forecast comparison involves the evolution of the definition of SMSAs and BEAs over time. Since the definition of these areas is dependent upon data that change over time (e.g. population), the county composition of the areas can be altered over the time that elapses between a model's estimation year and a forecast year. This factor affects both MRMI and MULTIREGION forecasts but, a priori, it appears to impact the MRMI forecasts more severely.

As a result of these factors, the model's forecast data are too dissimilar to be reasonably compared with each other through a comparison with a single data set. The procedure adopted, in light of the models' forecast dissimilarities, compared the forecasts of each model to data observed for the region for which a model makes forecasts (SMSAs for MRMI and BEAs for MULTIREGION). The comparison results should be interpreted as an insight into the separate model's general forecasting capability rather than an insight into the relative forecast accuracy of the individual models.

With the above caveats in mind, it is clear that comparing the individual model's forecast data with the REIS data can only yield gross generalizations about the relative usefulness of the two models. On this basis, the comparison procedure was established to minimize the factors limiting the models' comparability as follows.

- model forecasts for similar time periods (1975) were compared with observed data.

- model forecasts for similar regions were compared with observed data.

- model forecasts were compared to observed data from a data source using a single set of definitions and conventions.

The procedure yielded the data in Table 6-4.

The data in Table 6-4, columns 1 through 4, are: MRMI employment forecasts for various SMSAs (Column 1); REIS employment data (Column 2); the residual derived when REIS data are subtracted from the MRMI forecast (Column 3); the forecast error proportion derived by dividing the Column 3 residual by the MRMI forecast (Column 4). Columns 5 through 8 list similar data for MULTIREGION forecasts. Comparing the average absolute error for each model (listed in Columns 4 and 8 ) indicates that MULTIREGION forecasts appear to be slightly more accurate than those provided by MRMI. MULTIREGION's average error is about $8 \%$ whereas MRMI is approximately $11 \%$. A second observation, based on the data in Columns 3 and 7 , is that MRMI tends to overestimate employment while MULTIREGION tends to underestimate employment. Finally, MRMI forecasts appear relatively valid over the 10-year period from parameter estimation to 1975. MULTIREGION cannot be evaluated on this basis, as less than five years elapsed between parameter estimation and observation of the 1975 forecast. 
Table 6-4. MRMI AND MULTIREGION (MR) FORECASTS COMPARED WITH BUREAU OF ECONOMIC ANALYSIS 1975 EMPLOYMENT DATA

\begin{tabular}{|c|c|c|c|c|c|c|c|c|}
\hline \multirow[b]{2}{*}{ Area } & \multicolumn{4}{|c|}{ MRMI-SMSA Forecasts } & \multicolumn{4}{|c|}{ MR-BEA Forecasts } \\
\hline & MRMI & REIS & $\begin{array}{l}\text { MRMI } \\
\text { minus } \\
\text { REIS }\end{array}$ & $\frac{\text { MRMI-REIS }}{\text { REIS }}$ & MR & REIS & $\begin{array}{l}\text { MR } \\
\text { minus } \\
\text { REIS }\end{array}$ & $\frac{\text { MR-REIS }}{\text { REIS }}$ \\
\hline Atlanta & 831 & 868 & -37 & 0.04 & 1087 & 1188 & -101 & 0.08 \\
\hline Baltim ore & 958 & 964 & -6 & 0.02 & 1149 & 1081 & 68 & 0.06 \\
\hline Boston & 1756 & 1773 & -17 & 0.01 & 2794 & 2488 & 306 & 0.12 \\
\hline Buffalo & 611 & 531 & 80 & 0.15 & 682 & 677 & 5 & 0.02 \\
\hline Chicago & 3699 & 3,320 & 469 & 0.14 & $353 \%$ & 3794 & 237 & 0.07 \\
\hline Cincinnati & 655 & 599 & 56 & 0.09 & 732 & 783 & -51 & 0.07 \\
\hline Clevelähd & 1018 & 925 & 93 & 0.10 & 1759 & 1739 & 20 & 0.01 \\
\hline Dallas & 859 & 1,240 & -381 & 0.31 & 1296 & 1390 & -94 & 0.07 \\
\hline Denvor & fil) & 695 & -87 & 0.12 & 600 & 828 & -139 & 0.07 \\
\hline Detroit & 2001 & 1,721 & 280 & 0.16 & 2081 & 2045 & 36 & 0.02 \\
\hline Houston & 1090 & 1150 & -60 & 0.05 & 1074 & 1416 & -342 & 0.24 \\
\hline Indianapolis & 562 & 532 & 30 & 0.06 & 680 & 694 & -14 & 0.02 \\
\hline Kansas City & 704 & 621 & 83 & 0.13 & 965 & 888 & 77 & 0.09 \\
\hline Los Angeles ${ }^{a}$ & 4485 & 4,413 & 72 & 0.02 & 4550 & 4737 & -187 & 0.04 \\
\hline Miami & 743 & 677 & 66 & 0.10 & 1102 & 1236 & -134 & 0.11 \\
\hline Milwaukee & 730 & 663 & 67 & 1.10 & 869 & 866 & 3 & 0.0 \\
\hline Minneapolis & 1040 & 995 & 45 & 0.04 & 1279 & 1389 & -110 & 0.08 \\
\hline New Drlegns & 466 & 500 & -34 & 0.07 & 756 & 788 & -32 & 0.04 \\
\hline New York ${ }^{b}$ & 7718 & 5542 & 2176 & 0.39 & 7715 & .7821 & -106 & 0.10 \\
\hline Pittsburgh & 1036 & 970 & 66 & $0.0 \%$ & 1336 & 1334 & 2 & 0.0 \\
\hline Philadelphia & 2277 & 2005 & 272 & 0.14 & 3100 & 3115 & -15 & 0.01 \\
\hline Portland & 494 & 508 & -14 & 0.03 & 674 & 795 & -121 & 0.15 \\
\hline St. Louis & 1130 & 1038 & 92 & 0.09 & 1284 & 1429 & -145 & 0.10 \\
\hline San Diego & 510 & 660 & -150 & 0.23 & 561 & 701 & -140 & 0.20 \\
\hline San Francisco & 1971 & 20451 & -74 & 0.04 & 2263 & 2740 & -207 & 0.08 \\
\hline Seattle & 707 & 641 & $\dot{b} b$ & 0.10 & 984 & 1045 & -61 & 0.06 \\
\hline Tampa & 432 & 504 & -72 & 0.14 & 677 & 843 & -166 & 0.20 \\
\hline Washington, D.C. & 1495 & 1571 & -76 & 0.05 & 1515 & 1825 & -310 & 0.17 \\
\hline Arithmetic Mean & & & & 0.11 & & & & 0.08 \\
\hline
\end{tabular}

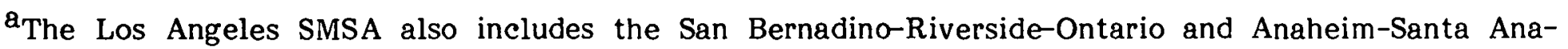
Garden Grove SMSAs.

${ }^{b}$ The New York SMSA also includes the Paterson-Clifton-Passaic and Newark SIVISAs.

${ }^{c_{T}}$ The San Francisco SMSA also includes the San Jose SMSA. 


\section{SECTION 7.0}

\section{CONCLUSIONS AND RECOMMENDATIONS}

As the preceding discussion and analysis indicate, no single model meets all the criteria listed in Section 2.0. In particular, no model comprehensively incorporates both interindustry and interregional linkages. To achieve the stated research objectives, it is therefore necessary to select more than one model. For interindustry analysis, the most useful model appears to be RIMS. The choice of RIMS is made for several reasons.

- RIMS is multiregional.

- RIMS data are available at the small-area level (SMSAs and BEAs).

- RIMS offers considerable sectoral detail (478 sectors).

- RIMS multipliers are based on regionalized interindustry relationships.

- RIMS multipliers appear to provide consistent estimates of "true multipliers" and their accuracy appears to improve for larger geographic aggregations.

Although RIMS contributes several of the capabilities desired, it cannot be used to analyze interregional effects. For interregional analysis, both MRMI or MULTIREGION appear to hold potential. Both models can be used to examine interregional linkages, but varying methods result in different capabilities. MRMI procedures forecast with greater sectoral detail. MULTIREGION, while not offering the same degree of sectoral detail, appears to provide forecasts that are more closely aligned with observed data.

In view of the apparent detail/accuracy trade-off inherent in choosing one of these models, final model selection must be based on pragmatic considerations mentioned at the outset of this paper. The most important concern is flexibility. In operational terms, the flexibility required to assess diverse solar technologies and regional conditions lies in the hands of the model builders and research managers. To meet the needs of solar energy impact estimation (a very specific type of impact), the willingness of model builders and managers to make modifications to their model must be solicited. This last consideration may well be the most important in terms of developing the intended solar energy labor-impact-assessment methodology.

Regardless of which interregional model is chosen, that model will need to be integrated with RIMS. The ability to achieve this integration easily will also be an important consideration in model selection. 


\section{SECTION 8:0}

\section{REFERENCES}

1. Hearings before the Subcommittee on Energy of the Joint Economic Committee of Congress. Creating Jobs Through Energy Policy. Washington, D.C.: Ninety-Fifth Congress, Second Session; March 15-16, 1978 .

2. Olsen, R. J. MULTIREGION: A Simulation Forecasting Model of BEA Economic Area Population and Employment. Oak Ridge, TN: Oak Ridge National Laboratories; 1977.

3. Greenwood, Michael J. "Research on Internal Migration in the United States: A Survey." Journal of Economic Literature. Vol. 13: June 1975, pp. 397-443.

4. Palmer, Charles; et al. "I-O Concepts." Regional Development and Plan Evaluation; Agriculture Handbook No. 550. Washington, D.C.: Economics, Statistics and Cooperation Service, U.S. Department of Agriculture, May 1978; p. 24.

5. Dickerman, Alan R. "Estimating Regional Net Trade Flows and Income Multipliers from Secondary Data: An Application of Keynesian Theory." The Annals of Regional Science. Vol. 9 (No. 3 ): November 1975; pp. 44-50.

6. Polenski, Karen R.; et al. A Guide for Users of the U.S. Multiregional Input-Output Model. Washington, D.C.: Office of Systems Analysis and Information, U.S. Department of Transportation; June 1972.

7. Harris, Curtis C., Jr. The Urban Economies, 1985. Lexington, MA: D.C. Heath \& Co.; 1973.

8. U.S. Water Resources Council. 1972 OBERS Projections of Economic Activity in the United States, Vol. 1. Washington, D.C.: U.S. Water Resources Council; April 1974.

9. Donnelly, William A.; et al. Estimating a Comprehensive County-Level Forecasting Model of the United States-READ. Washington, D.C.: Federal Energy Administration; 1977.

10. Energy Information Administration. State Earnings Analysis for the Administrator's Annual Report. Washington, D.C.: Energy Infor mation Administration; July 1978.

11. Bureau of Economic Analysis, U.S. Department of Commerce. Industry Specific Gross Output Multipliers for BEA Economic Areas. Washington, D.C.: U.S. DOC; January 1977.

12. U.S. Department of Census. County Business Patterns. Washington, D.C.: U.S. DOC; unnual.

13. Stenehjem, Eric J. Summary Description of SEAM: The Social and Economic Assessment Model. Argonne, IL: Argonne National Laboratory; April 1978.

14. Jurado, Gene. Regional Industrial-Occupation Demand Model. Washington, D.C.: Employment and Training Administration, Region VII, U.S. Department of Labor; 1978. 
15. Petersen, H. Craig. Sector-Specific Output and Employment Impacts of a Solar Space and Water Heating Industry. Washington, D.C.: National Science Foundation; December 1977.

16. Goldman, George; et al. San Francisco Bay Area Input-Output Model 1967, 1974. Berkeley, CA: Cooperative Extension Services; July 1978.

17. Weber, Joseph Carl. An Interindustry Economic Analysis of Northwestern Colorado. Ph.D. Dissertation; Colorado State University; Fall 1976.

18. Gray, S. Lee; McKean, John R. An Economic Analysis of Water Use in Colorado's Economy; Completion Report Series No. 70. Fort Collins, CO: Colorado State University; December 1975.

19. McMenamin, D. G.; Haring, J. "An Appraisal of Nonsurvey Techniques for Estimating Regional I/O Models." Journal of Regional Science. Vol. 14 (No. 1): 1974. 